NBER WORKING PAPER SERIES

EDUCATION RESEARCH AND ADMINISTRATIVE DATA

\author{
David N. Figlio \\ Krzysztof Karbownik \\ Kjell G. Salvanes \\ Working Paper 21592 \\ http://www.nber.org/papers/w21592 \\ NATIONAL BUREAU OF ECONOMIC RESEARCH \\ 1050 Massachusetts Avenue \\ Cambridge, MA 02138 \\ September 2015
}

This paper was prepared for Volume 5 of the Handbook of the Economics of Education. We appreciate helpful comments from Rick Hanushek, Steve Machin, and Ludger Woessmann. All errors and omissions are our own. The views expressed herein are those of the authors and do not necessarily reflect the views of the National Bureau of Economic Research.

NBER working papers are circulated for discussion and comment purposes. They have not been peerreviewed or been subject to the review by the NBER Board of Directors that accompanies official NBER publications.

(C) 2015 by David N. Figlio, Krzysztof Karbownik, and Kjell G. Salvanes. All rights reserved. Short sections of text, not to exceed two paragraphs, may be quoted without explicit permission provided that full credit, including $(\mathcal{O}$ notice, is given to the source. 
Education Research and Administrative Data

David N. Figlio, Krzysztof Karbownik, and Kjell G. Salvanes

NBER Working Paper No. 21592

September 2015

JEL No. I20

\begin{abstract}
$\underline{\text { ABSTRACT }}$
Thanks to extraordinary and exponential improvements in data storage and computing capacities, it is now possible to collect, manage, and analyze data in magnitudes and in manners that would have been inconceivable just a short time ago. As the world has developed this remarkable capacity to store and analyze data, so have the world's governments developed large-scale, comprehensive data files on tax programs, workforce information, benefit programs, health, and education. While these data are collected for purely administrative purposes, they represent remarkable new opportunities for expanding our knowledge. This chapter describes some of the benefits and challenges associated with the use of administrative data in education research. We also offer specific case studies of data that have been developed in both the Nordic countries and the United States, and offer an (incomplete) inventory of data sets used by social scientists to study education questions on every inhabited continent on earth.
\end{abstract}

David N. Figlio

Institute for Policy Research

Northwestern University

2040 Sheridan Road

Evanston, IL 60208

and NBER

figlio@northwestern.edu

Krzysztof Karbownik

Institute for Policy Research

Northwestern University

2040 Sheridan Road

60208 Evanston IL

USA

krzysztof.karbownik@ northwestern.edu
Kjell G. Salvanes

Department of Economics

Norwegian School of Economics

Hellev. 30, N-5035 Bergen

Norway

and IZA and CEPR

kjell.salvanes@nhh.no 


\section{Education Research and Administrative Data}

\section{Introduction}

Thanks to extraordinary and exponential improvements in data storage and computing capacities, it is now possible to collect, manage, and analyze data in magnitudes and in manners that would have been inconceivable just a short time ago. From 1986 to 2007, the world's capacity to store data increased from 539 MB per capita to $44,716 \mathrm{MB}$ per capita, with 81 percent of that growth occurring over the last seven years of that time period (Hilbert and Lopez, 2011). Over the same time period, computing speed increased at an even faster pace - from 0.09 million instructions per second on general-purpose computers in 1986 to 239 million instructions per second in 2000 to 28,620 million instructions per second in 2007 (Hilbert and Lopez, 2011). And while we do not have comparable statistics for the past seven years, computing speed and capacity growth has surely continued unabated.

As the world has developed this remarkable capacity to store and analyze data, so have the world's governments developed large-scale, comprehensive data files on tax programs, workforce information, benefit programs, health, and education. Today, in many countries around the world, governments collect, maintain, and store an archive of information regarding a vast range of behaviors and outcomes over an individual's entire lifetime (Card et al, 2010). Governments have established statistical offices to maintain and use these data to produce official statistics about their populations. In the education sector, governments have invested large sums of funds to develop longitudinal data systems. For example, in the United States, the federal Department of Education has invested over $\$ 750$ million to help states build, populate, and maintain these data systems. Much of this innovation in the United States came about as part of school accountability systems, and accountability systems still provide the backbone for the country's most frequently used databases.

At the same time, because administrative data sets are established for administrative purposes, they are not designed in a manner that makes them readily available for scholarly activity. In many locations, the data sets are administered by officials who also implement the policies for which these data were collected, and those who control access to the data may not be interested in evaluation of the policies they 
oversee. Moreover, the structure of administrative data - with a set of records for each administrative event, be it a point in time record about school attendance or workforce participation, a test score, a disciplinary infraction, a residential move, or a class taken offers both complications and new opportunities of statistical analysis along a vast range of substantive areas.

While these data are collected for purely administrative purposes, they represent remarkable new opportunities for expanding our knowledge and, through the conduct of analyses with more comprehensive data and better sources of exogenous variation than could typically be used in times past, challenging conventional wisdom in many areas based on previous research utilizing other sources like surveys. Administrative data also facilitate study of research questions that have heretofore not been possible to study credibly at all. Researchers who are able to access these data, especially those able to link data across administrative domains, have the ability to make extraordinary scientific advances by exploiting the population-wide data sets combined with the increased opportunity for identification of causal effects through exogenous variation by, for instance, policy changes, natural disasters, and other shocks that affect some groups of people but not others. In addition to natural experiments, these data can facilitate the conduct of field experiments, where the subjects of short-term experiments can be followed administratively for a longer period of time in manners that would have been impossible or prohibitively expensive to do absent large-scale administratively-collected data. The new insights from these studies have extraordinary potential to inform education policy and practice, and we document some cases where new policies have been based upon insights from these studies. Indeed, the massive growth in the quality and diversity of economic research on educational topics is certainly related to the increased availability of good administrative data.

This chapter describes some of the benefits and challenges associated with the use of administrative data in education research. We also offer specific case studies of data that have been developed in both the Nordic countries and the United States, and offer an (incomplete) inventory of data sets used by economists to study education questions on every inhabited continent on earth. 


\section{The benefits of using administrative data in education research}

Administrative data sets are not a panacea. They are limited to certain locations, which can decrease generalizability. It's hard to know whether a research study from Colombia or North Carolina or Norway or Romania will translate into different contexts. Administrative data sets often measure variables in a manner that is conducive to administration of programs, say, but are not necessarily ideal for research purposes. And administrative data sets are not necessarily structured in a manner that ensures data quality similar to the one in purpose-built research data sets.

That said, while traditional purpose-built data sets have many strengths, administrative data sets offer a number of clear advantages for empirical research in education. One clear advantage involves the ability to study population-level data. This ability offers a number of remarkable new possibilities. Perhaps the most obvious involves statistical power - in contrast to data sets with hundreds or thousands of observations, administrative data sets with many times that number of observations mean that it is often (depending on research design) possible to detect modest but meaningful relationships with much greater precision than was previously possible. But there are at least two other distinct advantages of administrative data that are afforded by the large magnitudes of observations. One involves the ability to detect rare events that might be useful for identification: In administrative data sets, it is often possible to make twin comparisons or study children from three-child families; to investigate the effects of extremely rare climatic or seismic events; or to study specific economic events like plant closures (Card et al, 2010; Roed and Raaum, 2003). In traditional purpose-built data sets, it is rare to have sufficient numbers of observations to be able to carry out analyses of these types. Another major advantage of having large-scale administrative data is the ability to study heterogeneous effects of educational policies and practice: With very large numbers of observations, it becomes possible to see whether the effects are similar across wildly different groups of individuals, and if they differ, how they differ, and for whom.

Allowing for new identification strategies and for the ability to see how generalizable results are across groups are two major advantages of the population-level nature of administrative data, but they are not the only benefits. Because data coverage is 
universal, it becomes feasible that one can link administrative data from one domain (e.g., education) to data from another domain (e.g., workforce or health). While it is certainly possible to compare across domains in non-administrative settings, doing so is considerably more difficult because people would have to be purposefully longitudinally followed, and because a cross-section of educational data, say, and a cross-section of health data may only include some of the same individuals by happenstance. Administrative data, by virtue of their population-level nature and the frequency of data observation, allow the researcher to follow individuals or entities over time, so that there is a panel structure to the data.

Administrative data sets also provide novel types of variables typically not found in non-administrative data (Einav and Levin, 2013). They can offer new opportunities, for instance, to look at measures of delinquency, of changing geographical location, of social networks, and of health instances that are nearly impossible to study in any other manner. The real-time nature of administrative data also provides new opportunities to study the effects of educational policies and practices that are very recent; and offers the chance for researchers to make their scholarship much more relevant to the specific policy decisions that policymakers must make right away than are studies that make use of retrospective information (Einav and Levin, 2013). And of course, natural experiments need not be rare events to be better-studied using administrative data sets: Because natural experiments are unannounced, and often occur via chance or quirks, it is very difficult to set up a prospective study that will permit the evaluation of a natural experiment; with administrative data that cover a population and that are recorded regularly, it is much more feasible to ex post identify and study these natural experiments (Roed and Raaum, 2003).

The preceding description of advantages of administrative data makes clear the benefits of these data for identifying causal effects. But these data are also highly beneficial for the identification of structural parameters of human behavior for multiple reasons. First of all, the population-level nature of administrative data means that these data are representative of a given population. In addition, the administrative data, through the variety of records across a set of domains, both simultaneously and over-time, allows the structural analyst with the opportunity to simultaneously model a set of complex 
relationships that would almost surely not be possible to uncover using retrospectivelycollected data (Roed and Raaum, 2003). The lack of a specific structure of administrative data can also facilitate reduced-form analyses, because data that are recorded as a series of observations but without a distinct structure can be rearranged to build rectangular panel data sets that have precisely the properties that are more ideal for the specific empirical task at hand (Eivan and Levin, 2013).

Another benefit of administrative data is that data quality is likely to be simply better than retrospective data collection. Rather than ask people whether they participated in a given program twenty years ago, scholars who make use of administrative data can observe directly whether the individuals participated - according to the authorities who paid for the participation and therefore had a strong interest in correctly recording the occurrence! Also because of the mandatory nature of participation in the activities that generate administrative data, these data are much less likely to suffer from attrition problems or non-response problems than are data collected through voluntary means (Card et al., 2010). Likewise, administrative data are likely to be less subject to overreporting or under-reporting of key variables.

Administrative data also facilitate the study of intergenerational issues. It is possible, at least in some contexts, to match children's administrative records to that of their parents, and even grandparents. While it is certainly possible to purposefully follow families longitudinally, the risk of attrition is surely greater when attempting to move from one generation to the next than if it is possible to directly match individuals using administrative means (Roed and Raaum, 2003). And, in the case of questions that require a long amount of time to study in real time (e.g., intergenerational isssues), the time horizon over which intergenerational questions may be studied can be shrunk considerably with administrative data.

Using administrative data has major practical value as well. Importantly, different countries have extremely different policy environments. While it is possible that in some circumstances, a study conducted in Denmark would be just as relevant to Chile as would be a study conducted in Chile, or vice versa, there are many cases - because of different institutions and different populations - where it makes the most sense to study a specific question in the location where the policy environment is what the researcher most wishes 
to study. And, of course, this demonstrates the real benefit of comparative work across jurisdictions: If a result is similar across very different populations or very different policy environments, this lends additional credence to the idea that the result is general. Likewise, we can learn a lot from studying how different are the outcomes in jurisdictions where the policy environment is very different from one another. In sum, some research is transferrable and we can learn a lot from work done in other countries, but other research is best conducted locally, suggesting a benefit to many countries developing, maintaining, and sharing with researchers their administrative data (Card et al., 2010).

In summary, administrative data are more comprehensive than are purpose-built survey data, and can be collected with frequently far more accurate information. Furthermore, the costs of conducting research with administrative data are much lower as well, at least once the data systems are developed. Once data structures are established, linking and extracting more records from administrative data cost only the time of the programmer, and the marginal cost of adding additional individuals or periods of data to the analytical sample is extremely small, suggesting remarkably large economies of scale associated with administrative data (Roed and Raaum, 2003). While there are obviously many important roles for purpose-built survey data - not least the fact that only with purpose-built data it is possible to study precisely the questions that one wishes to study in exactly the manner in which one wishes to study them - it is also evident that administrative data offer numerous new opportunities to conduct research on questions that were previously impossible to study, or at least to study so well. Indeed, administrative data and survey data, while sometimes substitutes, can frequently be considered complements, as when administrative data can reduce the set of questions that need to be answered via surveys, or when administrative data can be used to serve as a check on the reliability of retrospective information collected via surveys (Roed and Raaum, 2003). Administrative data can also be thought of as complementary to the conduct of field experiments, as the costs of tracking and following up with field experiment participants are much lower, and the data frequently much better, when the field experiments can be linked with data collected by governments for administrative purposes (Card et al., 2010). For all of these purposes, having a high degree of access to 
administrative data makes a wide range of empirical studies in education more feasible and more believable.

\section{Case studies}

The Nordic countries, notably Denmark, Sweden, Norway, Finland and to some extent Iceland, established administrative registers in the mid-1960s. When populationwide social security systems were established, there was a need for a unique personal identifier in order to follow people across jobs and other labor market states and collect information on earned pension points. These population-wide identifiers were then adopted for all administrative registers from birth registers to cause of death registers, and included in registers covering education and labor market participation, as well as for linking members of families together. The core of these registers is thus the universal system for identification numbers covering everybody from date of birth (or immigration) and identical across all administrative units. The identification number system was based on the 1960 census and for some of the countries also local (municipality level) registries of populations. This also implies then that people born several decades prior to 1960 are covered. And for instance for Norway, a job has been done more recently to uncover time and place of birth, and for some registers and cohorts also parental background.

The Nordic countries have established mechanisms to share these data with members of the research community for specific research projects, and several research groups in each country have now access to portions of the register data linking some of these data sets depending on the focus of research. ${ }^{1}$ In the case of each research project, both the administrative units who administer the data as well as the national Data Inspection Authority must consent to the use and matching of registers based on a detailed application procedure. Since the registers contain sensitive and very private information, the national statistical offices link the registers for research purposes and provide identification numbers for researchers that are different from the actual administrative identification numbers.

\footnotetext{
1 This overview focus on registers used for research with a focus on education in wide sense and a lot of register based research using Norwegian data is not included. For instance, Roed and Raaum (2003) describe the collection of registers for one research group focusing mainly on labor market outcomes.
} 
There are some common core data sets in all the Nordic countries such as family links, several education registers for test scores at different levels, completed education etc., and labor market outcomes and income. The countries do, however, differ to some degree when it comes to, for instance, availability and access to health data, vital statistics, etc. The Nordic countries also differ in terms of how far back in time data sets are linked and available for potential research use. Of course, being data collected for administrative purposes, when data are available to study the introduction of a given program or policy, it is generally by good fortune rather than prospective design, and it's also the case that many policy programs are unique to each country.

In this section we offer three case studies of some of the data potentially available to researchers in different jurisdictions, and how they have been used. Our case studies are two Nordic countries - Norway and Sweden - as well as the state of Florida. These are not intended to be complete overviews, but are rather examples of some representative uses of administrative registers. When appropriate, we also mention some complementary work conducted outside of the countries featured in the case studies.

\section{A. Norway}

Most of the research using register based data sets in Norway have exploited the joint advantages of access to long panels of data combined with parental background and child outcomes along many dimensions, and the fact that population-wide data provides the opportunity of using policy reforms back in time for identifying causal effects. In education research, one example of this strategy is assessing the causal effect of parental education on children education exploiting a mandatory school reform for parents (Black, Devereux and Salvanes, 2005a). In this paper, a parent cohort from the late 1940s to the late $1950 \mathrm{~s}$ and their children are used to estimate the intergenerational transmission of education, using the panel structure of the data as well as the family links. In addition, a mandatory school reform rolled out across 700 municipalities in a period of ten years for the parental generation, which is used to identify the causal effect of the educational transmission across generations. Due to the population wide data set, the analysis could 
also be undertaken for different education subgroups, for instance whether mothers or fathers or both were affected by the reform, and for different education levels. ${ }^{2}$

Family links for the whole population combined with the long term panel structure following people from birth to adulthood have also been essential in the recent research using register data in Norway and the other Nordic countries. Examples of this line of research is Black, Devereux and Salvanes (2005b, 2007). Both these papers study family dynamics in the sense of the effect of family size and birth order, or child health on a set of long term outcomes in education and the labor market.. Both papers need to match long term outcomes from a large set of registers measuring adult outcomes, such as several measures of education (years of education, completing high school, college attendance), as well as outcomes in the labor market including working and annual earnings. In Norway, a person register that links family members to one another by relationship facilitates the study of questions such as birth order effects by family size (Black, Devereux and Salvanes, 2005b). Black, Devereux and Salvanes (2007) further use a register of twins, including monozygotic twins, to identify the effects child health on long term outcomes. For child health birth weight was used which required merging in the Norwegian birth registry. Bharadwaj, Loken and Neilson (2013) use a very similar data set to assess the effect on test scores in school of medical treatment just after birth for just above or just below very low birth weights.

Early investment and long term outcomes has been another important part of the agenda for Norwegian researchers using these data sets - especially using family policies for identification. One of the obvious advantages of using the Norwegian data register data is that since the data goes long back, many of the family policies and education policies which were part of the developing welfare state can be analyzed. A notable example of this approach is Havnes and Mogstad (2011) who study the long run effects on children's education and labor market outcomes by exploiting the fact that a day care reform was rolled out across municipalities in the late 1970s and early 1980s. Similarly, Bettinger, Haegeland and Rege (2013) investigate a program that increased parents' incentives to stay home with children under the age of three. They assess the effect on

\footnotetext{
${ }^{2}$ See Bjorklund and Salvanes (2011) for an overview of the international literature on the intergenerational mobility of education, also discussing other identification strategies.
} 
older siblings' 10th grade GPA, and find support for a positive effect that seems to be driven by mother's reduced labor force participation. Another reform used for identifying the effect of even earlier investment in children on adult outcomes, is an extension of a maternity leave program that came into force on July 1, 1977. This sharp cutoff in eligibility depending on the exact date of birth is well-suited for a regression discontinuity design approach (Carneiro, Loken and Salvanes, 2014), and here especially the value of large population-level data is on display, as one requires very large data sets in order to execute very data intensive non-parametric approaches. Interestingly, fairly strong effects on children's medium and long term outcomes were found for staying longer home after birth with the mother. On the other hand, analyzing extensions of the maternity leave reform of up to one year fully covered leave, and using the same estimating strategy does not seem to give a positive effect on children's outcomes (Dahl, Loken, Mogstad and Salvanes, 2013). There clearly seem to be decreasing returns also to this input in the production function of children.

Several other strategies have been exploited to assess the effect of early investment, especially related to the effect of parental income, on in-school education outcomes, and a variety of long-run outcomes. Rege, Telle and Votruba (2011) evaluate the effect on children's test score in middle school using job loss from mass lay-offs for identification. They find an asymmetry in the effect of father's and mother's job loss - a negative effect on grade point average in $9^{\text {th }}$ grade for father's job loss and a positive effect of mothers. The authors interpret their results as not an effect of income but of distress form job loss which is strongly negative for men. Black, Devereux, Loken and Salvanes (2013) analyze the effect of child care subsidies on children's long term education using a sharp discontinuity in the price of childcare in Norway. They find significant positive effect of the subsidies on children's middle school performance. This suggest a positive shock of disposable income on children's school performance. Carneiro, Lopez-Garcia, Salvanes and Tominey (2014) use very similar data to assess the effect of timing and possible dynamic complementarities of parents income on children's short term and long term outcomes both in completed years of education and performance in the labor market. The rich data provides an opportunity to use non- 
parametric methods, and supports findings that not only the discounted life time income but also timing matter, which supports the dynamic complementarities hypothesis.

Since the early 2000s grades in high school and middle school have been available as well as national tests for some years in primary school. The register of school grades combined with school resources and information on teachers have been exploited to answer a more traditional questions in the literature on the economics of education. Leuven and Ronning (2011) use grades in middle school to study the effect of class size on students' achievement exploiting a version of the Maimonides rule, while Haegeland, Kirkeboen, Raaum and Salvanes (2011) use the same pupil performance register, but a wider school resource measure and different identification strategy - a local hydro power plant tax. Both find small effects of resource use on children's school performance. Thanks to the population-wide register data comprising all pupils at a grade level, peer effects may be identified. Leuven and Ronning (2014) use the same performance register but add in detailed information on school grade mixing. They find positive effects on pupils mixed with older peers. Black, Devereux and Salvanes (2011) exploit this and assess the effect of the quality of peers using within school changes across years in the composition of pupils. Using data going longer back in time, they are able to assess the long term peer effects. In another paper, Black, Devereux and Salvanes (2013) analyze the role of school starting age on cognitive outcomes such as IQ tests for boys at age 18, and for longer-run outcomes such as educational attainment, teenage pregnancy, and earnings. The important issue in this literature is to separate school starting age from test age. Exploiting variation in the mapping between year and month of birth and the year the military test is taken, allowed the analysis to distinguish the effects of school starting age from pure age effects. Findings provide evidence for a very small positive effect of starting school younger on IQ scores measured at age 18. In contrast, they find evidence of much larger positive effects of age at test, and these results are very robust.

Another well-studied area in the economics of education where long panels of register data may be helpful in making progress is in answering the seemingly simple question of what are the returns to education? Exploiting Norwegian population panel data with nearly career long earnings histories, a detailed picture of the causal relationship between schooling and earnings over the life cycle can be analyzed (Bhuller, 
Mogstad, and Salvanes, 2013). These authors estimate internal rates of returns over lifetime earnings from age 17 to the mid-60s for many cohorts, and make use of a direct measure of life-time earnings instead of approximating earnings using one year or an age groups, and thus, avoiding the problems of Mincer life-cycle bias. When doing so, they find evidence that the estimated returns to schooling are biased downward.

Administrative data have already been in use, in particular in the Scandinavian countries, for some years, and the enhanced knowledge from these studies have already informed policies and we are starting to see the fruits of these new insights in active policies. In Norway, the most striking example is a strong focus that politicians have recently put on pre-school or early investment in children. As a part of a surge in the interest in early investment in children and children outcomes, the focus among researchers in Norway has been to exploit the possibility for assessing long-term outcomes in education and the labor market. Both the effect of maternity leave, a daycare roll out for preschool children as well as other programs increasing for instance parents time use in preschool children, have painted quite a consistent picture of the importance of early investment for medium and long term cognitive outcomes. These findings together with the international evidence - have informed the public debate and later led to policy proving stronger incentives for more resource use in for instance preschools in Norway. Different from the system in the United States, in the Scandinavian countries the way that this type of research may penetrate the public debate and also inform the ministries and politicians, is mainly through forming groups of academic "experts" in a particular area. The "experts" document the new insights from research in the area, and write a report to the Government. In this case a group of experts, including economists who do research on early investment using administrative data, drafted a review of the findings and also came up with concrete suggestions for how to improve both the coverage and quality of preschools in Norway (NOU 2010:8). Based on reports like this a white paper will be written to the Parliament with suggestion of a law change or suggestion for reallocation of money to preschools. There are also several other examples for Norway of how new research based on administrative data informs politicians and leads to law changes outside the area of education, for instance from newly gained information on how the labor market functions. 


\section{B. Sweden}

The Swedish data infrastructure is constructed in a very similar way to Norwegian data described in the section above. The data comes from local and national registers and is maintained by municipalities and Statistics Sweden. Each Swedish resident is assigned a unique and permanent identification number at the time of their birth and each immigrant is assigned a similar number if they immigrate to Sweden for more than 6 months. ${ }^{3}$ These unique numbers are recorded in every administrative database, be it local or national, and allow merging different registers together. They are also used in surveys and experimental studies (Meghir and Palme, 2005; Hinnerich, Hoglin and Johannesson, 2011; Fredriksson, Ockert and Oosterbeek, 2013; Golsteyn, Gronqvist and Lindahl, 2014; Jalava, Joensen and Pellas, 2015) ${ }^{4}$.

Historically Sweden conducted only population censuses at national level and maintained birth and death records at parish level. Similar to Norway, this changed in the 1960s when Statistics Sweden (SCB) started building their registry data. Today SCB maintains four core registers that together contain more than 50 different thematically focused sub-registers. These four core data sets cover population (e.g. employment or education registers), activity (e.g. earnings or pupils registers), real estate (e.g. prices or GIS registers) and business (e.g. patent or schools registers). In addition to these SCB registers, the National Board of Health and Welfare maintains more than 70 registers with individual level medical diagnoses ${ }^{5}$. The registers are accessible to research community through Statistics Sweden, various research institutes (e.g., the Research Institute in Industrial Economics, or IFN) or governmental agencies (e.g., the Institute for Evaluation of Labour Market in Education Policy, or IFAU). Access is granted on project-by-project basis and each application undergoes detailed investigation. Different registers are merged by SCB and researchers obtain data sets with a new unique, but randomly generated, individual identifiers.

\footnotetext{
${ }^{3}$ When the system was created in the 1960 s all the living Swedes were also assigned unique identifiers retrospectively.

${ }^{4}$ Jalava, Joensen and Pellas (2015) evaluate short term effects of experimental intervention in Stockholm schools, and their subsequent research will merge in registry data to study longer-run outcomes.

${ }^{5}$ Similar data exist in a number of locations including Manitoba (Currie et al., 2010) and Denmark

(Dalsgaard, Nielsen and Simonsen, 2014).
} 
Due to security and data management reasons SCB maintains different educational databases under different "big registers", and hence for a given project these need to be merged with one another. For instance, Fredriksson, Ockert and Oosterbeek (2013) investigate the long-run effects of class size, and their baseline data set is actually a purpose-built longitudinal survey run by the Department of Education at Gothenburg University. However, since the subjects in this survey all have unique identification numbers it is possible to link them back to other administrative data sources. In particular, the authors add data on class size from class registers, parental information from multigenerational registers, medium-term achievement from compulsory school pupil registers and military draft registers, completed education from education registers, earnings from statement of earnings registers and wages from wages and staff for public and private sector registers. On the one hand, this decomposition illustrates the complexity of the data structure and emphasizes the crucial role of unique personal identifier. On the other hand, such a complex structure enhances the security of the very sensitive personal information and improves the management of the data.

The long panels and retrospective assignment of unique individual identifiers allow studying lifecycle and multigenerational effects also in the case of Sweden. Meghir and Palme (2005) study the effects of comprehensive schooling reform that among other elements increased the length of compulsory schooling, and was introduced in the late 1940s. They utilize survey data on two cohorts that are then linked to registry data which provide individual educational attainment and earnings. Meghir, Palme and Schnabel (2012) utilize the same reform, richer data set and show that it not only reduces the criminal activity of the treated generation but also of their children. Even more data demanding endeavor is undertaken by Palme et al. (2015) where they combine Swedish registers and historical survey records to estimate the intergenerational persistence of human capital, measured by educational attainment, across four generations.

Both Norway and Sweden share two very unique and purpose built data sets: military assessment and adoptions. The former one provides physical, cognitive and noncognitive assessment of all males at the age of 18-19 (Lundborg, Nilsson and Rooth, 
2014) ${ }^{6}$. The latter one contains all persons who were born in Sweden between 1962 and 1996 and adopted by both parents (Bjorklund, Lindahl and Plug, 2006; Holmlund, Lindahl and Plug, 2011) ${ }^{7}$. Together with the ability to link these data to population registers they provide social scientists with extremely powerful analytical tool. There are also several other purpose built survey data sets in Sweden. Fredriksson, Ockert and Oosterbeek (2013) use the Gothenburg University panel mentioned above containing cognitive test scores for 13 year olds. Golsteyn, Gronqvist and Lindahl (2014) use the Stockholm Birth Cohort Study, which contains information on children's time preferences at age 13. In the paper the authors link this survey to administrative data and conclude that adolescent time preferences predict outcomes up to five decades later in life.

Although Sweden, and likewise Norway and Denmark, seem like ideal places for empirical studies on the intersection of family, health, education and labor markets, there are still many challenges in carrying out this research in reality. The two main obstacles in educational research are that authorities tend to be reluctant to allow the conduct of field experiments, as well as the lack of longitudinal assessment data. Scandinavia, including Sweden, lags far behind the United States in the implementation of the field experiments related to student incentives (Fryer, 2014), student support (Cook et al., 2014), teacher incentives (Imberman and Lovenheim, 2015), school choice (Deming et al., 2014) or school management (Fryer, 2014). Given the problems with tracking students over time in the United States, the Scandinavian administrative data infrastructure is ideal to study long-run consequences and potential positive and negative spillovers of policy interventions, and field experiments are current gold standard in policy evaluation.

That said, the Scandinavian countries do have a fair degree of assessment data of late. Sweden, similar to Denmark and Norway, introduced in recent years some form of longitudinal assessments in their compulsory schools. The longitudinal assessment data in Sweden began in 2009 and comprise of tests given in grades three, six and nine. The

\footnotetext{
${ }^{6}$ Since the mid 2000s the draft is no longer mandatory in Sweden so the data does not provide information on the whole population. The draft continues to be mandatory in Norway. Finland has also mandatory military draft (Kerr, Pekkarinen and Uusitalo, 2013).

${ }^{7}$ The register is now expanded to cover more recent birth cohorts.
} 
assessment data in grades 3 and 6 have not been widely used in research thus far ${ }^{8}$. Before this reform Swedish students were only assessed at the age 16. These data on compulsory school exit exams are available since 1988, and have been often used, for example by Almond, Edlund and Palme (2009) who study the effects of prenatal exposure to radioactive fallout on school outcomes. It is worth noting that unlike in the United States all tests in Scandinavian countries are low stakes and the Swedish Education Agency explicitly states that they "... are not examination, but should be part of the teacher information about student's knowledge..." In fact, except for Stockholm and Malmo, these virtually do not matter for high school admissions as children are guaranteed a place in their closest high school (Karbownik, 2014).

Sweden and Denmark, unlike Norway, have also implemented a large-scale refugee placement policy in a nearly random way. The placement assignment could be seen as random conditional on observables because the individual could not choose their first place of residence and there was no direct interaction between a refugee and placement officers. This does not guarantee that immigrants were randomly assigned to neighborhoods, in fact they were not, but the placement selection was based on observable attributes of immigrants and these are all available in administrative data. This policy has been extensively studied not only for its labor market consequences for immigrants themselves (Edin, Fredriksson and Aslund, 2003) but also for the educational consequences of their children (Aslund et al., 2011) ${ }^{9}$.

Sweden is also the only one of the Scandinavian countries that introduced some form of charter schools. Unlike in the US these have not been introduced with a random component and allow only for differences-in-differences type of identification. Sandstrom and Bergsrton (2005) study the effects of the reform, and the competition it induces, on quality of public schools. Bohlmark and Lindahl (2015) study its long-run consequences. Hensvik (2012) utilized the same reform to understand how competition affects teacher mobility and wages. Wikstrom and Wikstrom (2005) document that

\footnotetext{
${ }^{8}$ Raw scores are not kept by the authorities and for the early schooling test it is only the pass/fail indicator that is recorded in the registers. Although, from research perspective the more continuous score measure is very valuable this is a clear example where the research needs do not cross with the administrative needs, and indeed this data serves primarily administrative purposes for which a binary coding is sufficient.

${ }^{9}$ The Danish study uses the placement policy to study the effects of early exposure to neighborhood crime on subsequent criminal behavior of the youth (Damm and Dustmann, 2014)
} 
school competition leads to grade inflation, and that voucher schools inflate their students' grades more heavily. Sweden has also introduced two other market oriented educational reforms that have been evaluated by researchers. The first transferred the funding responsibilities from central government to local municipalities (Fredriksson and Ockert, 2008). The second allowed individual level wage bargaining between teachers and principals (Bohlmark, Gronqvist and Vlachos, 2012). Yet another school choice reform was introduced in Stockholm in 2000, and changed the high school admission system from one largely based on place of residence to another entirely based on compulsory school performance i.e. change from zoning to open enrollment. Soderstrom and Uusitalo (2010) document that the reform lead to sharp changes in student composition in Stockholm schools, while Karbownik (2014) shows that these changes in student quality lead to changes in teacher labor supply.

\section{Florida}

Due to the decentralized nature of education in the United States, there exists no prospect of national educational data records, at least in the foreseeable future. However, a number of states and school districts have established systems in which students can be followed longitudinally and matched to schools and, in some cases, their teachers over time. The three states with the longest-standing state level student longitudinal data systems that have been widely available for researchers are Florida, North Carolina and Texas.

Florida has maintained statewide records of student test scores that are longitudinally comparable (initially in grades 4, 5, 8, and 10, and soon thereafter expanded to grades 3 through 10) since the 1997-98 school year within its Education Data Warehouse (EDW). The EDW also includes information on high school graduation, grade retention, student attendance, disciplinary infractions, school assignments, home language, immigrant status, disability, race/ethnicity, gender, school transcripts, and a measure of student poverty, along with other measures. Florida assigns a unique identification number that remains with the student no matter which school district he or she attends within the state. Since 2001-02, Florida has linked students with their teachers 
in each class - permitting the matching of staff databases that include teacher credentials to their students.

A large number of papers have made use of these student-level longitudinal data to study a wide range of research questions. For example, Chiang (2009), Figlio and Rouse (2006), Rouse et al. (2013), and West and Peterson (2006) identify the effects of changing school-level accountability pressure on student test performance in public schools, and Figlio and Lucas (2004) investigate the degree to which school accountability policies affect student sorting across schools. Sass (2006) and Booker et al. (2011) study the effects of charter schools on test scores and later outcomes. Figlio and Hart (2014) measure the degree to which public schools respond to the competitive pressure associated with school voucher systems. Harris and Sass (2011) study the effects of a variety of teacher qualifications and in-service training on teachers' contributions to student achievement, while Chingos and West (2012) investigate the relationship between measured teacher value added and labor market returns when those teachers leave teaching. Winters and Greene (2012) study the effects of a test-based promotion policy. Schwerdt and West (2013) evaluate the role of grade configuration on student outcomes. Burke and Sass (2013) identify classroom peer effect relationships.

The Florida Department of Education, in conjunction with other state of Florida agencies, has successfully linked K-12 data with a variety of post-secondary data sources, including information on post-secondary education and training, employment and earnings records, military service and criminal justice records. These matched data sets, known as the Florida Education and Training Placement Information Program (FETPIP), have followed students in Florida beginning with the 1996-97 high school graduation cohort, so earnings data are now available for individuals as late as their early midcareers. A number of important papers have been written that have linked FETPIP data to K-12 education records. For instance, Clark and Martorell (2014) compare labor market outcomes of students who barely passed high school graduation examinations to those who barely failed these examinations to identify the degree to which a high school diploma has signaling value in the labor market. ${ }^{10}$ Other papers follow people from the education data sets into the labor market. In a particularly inventive use of these data,

\footnotetext{
${ }^{10}$ Clark and Martorell (2014) also make use of data from Texas to perform a parallel exercise in that state.
} 
Chingos and West (2012) relate teachers to students' test scores to obtain measures of teacher "value added", and then observe whether teachers with higher measured value added command higher labor market earnings in the event in which they leave public school teaching. Both of these papers offer glimpses into the types of analyses that are possible when it is feasible to link education records - both those of students and those of teachers - to labor market records.

In recent years, it has become possible to track Florida students not just forward into the labor market but also backward to early childhood program participation and birth records. For a series of projects by Figlio, Roth and co-authors, the Florida Departments of Education and Health have matched the birth records of all children born in Florida between 1992 and 2002 to the school records observed by the Department of Education. To date, over 1.6 million children's administrative records have been matched between agencies for these research purposes. ${ }^{11}$ These matched data have made it possible to study questions ranging from the educational consequences of poor neonatal health (Figlio et al., 2014) through the effects of early interventions for autism spectrum disorders on children's educational outcomes (Currie et al., 2014) to the spillover effects of having disabled siblings on children's cognitive development (Black et al., 2014). The earliest of these birth cohorts are, at the time of writing, old enough to have graduated from high school, so soon it will be possible to follow children born in Florida through their K-12 schooling career and, thanks to the FETPIP data, into post-secondary education, the labor market, the military, and the criminal justice system.

These matched administrative data from Florida highlight some major benefits possible by virtue of the fact that they are drawn from population-level data. Consider, for instance, the three papers described in the preceding paragraph: None of these research projects could have been carried out without the benefit of population-level data because they each require large-scale data to study relatively rare events. Figlio et al. (2014) compare twin pairs with discordant birth weights; Currie et al. (2014) study children with autism spectrum disorders, accounting for fewer than one percent of the

\footnotetext{
${ }^{11}$ These data sets are linked by name, date of birth, and social security number (a national identification number). This three-factor linkage allows for much more accurate matching of data across administrative data domains than would have occurred with fewer linking factors (e.g., name and data of birth alone). See Figlio et al. (2014) for details.
} 
population; and Black et al. (2014) identify the effects of disabled siblings by comparing the outcomes of first and second-born children in three-plus-sibling families. Traditional surveys that follow children and families longitudinally are not equipped to study rare occurrences such as these. With population-level data, many new research programs can be launched at a fraction of the cost of purpose-built survey-based databases, and still more research programs that were previously infeasible or impossible to undertake are now possible to carry out.

These Florida data provide some distinct advantages over data sets observed in other jurisdictions. The ability to follow students longitudinally, to observe frequent assessment data and other student outcomes, and to link students to teachers - attributes not found except for very recently in some European registry data - allows researchers to study certain questions in the United States that are difficult to study in many other jurisdictions. Now that it is possible to link school records to later labor market data, and backward to birth and early childhood records, Florida is developing some attributes of the registries found in northern European countries. On the other hand, linked data for Florida children are only available for relatively recently-born children, and no information about parents, except that observed on a child's birth records, are currently linkable to children in Florida. In addition, given the fact that the United States is an open economy with high degrees of mobility across states, it is natural that there would be considerable attrition from even the most complete records. For instance, the birth records-school records linked data employed by Figlio et al. (2014) and others include only 81 percent of the children born in Florida between 1992 and 2002; the remaining children either left the state of Florida or enrolled in private schools and never were included in the public school records. While careful checks of other data sources make clear that virtually all of the children whom one would have expected to have been matched between these data sets were ultimately matched, this highlights the shortcomings of matched birth and school records in the United States context. Nonetheless, the data from Florida highlight some of the limitless possible populationlevel research programs that matched administrative data sets could facilitate in the United States and around the world. 
As in the Scandinavian context, research using administrative data from Florida has led to substantial policy changes. Noteworthy examples include how school voucher policy in Florida (and in several other states in the United States) has been influenced by research documenting the effects of school vouchers on selection, participation, and competition; and how the state changed its compensation policies regarding the accumulation of teacher credentials (in particular, National Board Certification) once research identified the degree to which the attainment of this credential influenced - or failed to influence - teacher performance in the classroom. These examples, coupled with other cases both in Florida as well as around the country, such as how North Carolina maintained an early childhood enrichment program when presented with research evidence documenting its efficacy (Cite, XX), or how Washington changed its teacher retention policies after research showed the relatively limited relationship between teacher experience and value added in the classroom (Cite, XX), demonstrate the ways in which administrative data in education have not only led to scholarly advances but also are beginning to result in research-driven policy and practice changes.

\section{Challenges associated with the use of administrative data}

We have so far stressed the important advantages of administrative registers as compared to survey data - fewer issues with recall and other measurement problems; since its population-wide the data set is representative; less problems with attrition compared to surveys that follow the sampled populations over time; less problems with non-response; and the ability to study heterogeneous effects and rare and infrequent events. Combined with data for public policies in the past, many credible policy evaluations such as education policies and family policies as described above can be analyzed. Complete family links makes it possible to exploit other "experiments" for identification such as comparing siblings and twins as well as the use of adoptees. The long panel structure of administrative registers makes it possible to assess the effects of policy programs both for short and long terms outcomes across a large number of outcomes and across many administrative unites. 
However, there are certain limitations or restrictions related to the use of administrative register data, and we try to distinguish between three different aspects of restrictions as compared to surveys designed for particular research questions.

\section{A. Limited information/less flexibility than with purpose-built surveys}

Administrative registers are collected for different reasons than research, and in particular in one area they have limitations as compared to purpose-built surveys. Very little information on cognitive skills other than achievement and attainment or social and behavioral skills are available in most register data. Variables that potentially are very important in understanding for instance school choices such as motivation and attitudes and more general psychological traits for instance as measured by Big five components are not available. Some of these questions are available in some countries in military data for men, but usually only for a limited number of years.

This lack of important information on, for instance, reasons for education choices or effort is a challenge, but several new strategies are being used to mediate this limitation. Several research groups in the Nordic countries are now combining surveys with registers data, as well as lab experiments and randomized field experiments with register data.

One example connected to the economics of education undertaken is in Norway, where pupils just prior to the decision to attend high school, were surveyed on the "Big five" personality traits and on the information about the labor market (Almas, Cappelen, Salvanes, Sorensen, Tungodden, 2014). The idea in the project was to use incentivized lab experiments to tease out preferences for willingness to compete, risk taking, patience etc., together with an ability test, a survey regarding the "big five", time use on homework etc., and a quite intensive survey on the students' knowledge of the labor market and the returns to education. Parents and students provided consent to follow these students through the education system and into the labor market, and to match to parental background from register data. Many research questions may be analyzed using this resource, for instance to better understand high drop-out rates. These type of approach also facilitates field experiments in school, and then allows following pupils 
through the education system, into the labor market. Hence, the lack of information in the administrative data sets may be compensated in different ways.

\section{B. Technical issues with the use of administrative registers}

Depending on the country, issues of a more technical nature might be an obstacle in the use of administrative registers. One such obstacle is the ability to match administrative registers across administrative units. For instance, important research topics can be analyzed by connecting school outcomes to long term outcomes such as income and completed education, or even outcomes such as fertility, crime, and marriage. In many countries, and notably the Nordic countries a common identification number is utilized across all administrative units and across all registers. Furthermore, even if the different administrative registers are collected and owned in principle by the different units, a law for statistical usage for research purposes enables researchers to use merged registers across administrative units. De-identified and merged data are made available through the national statistical offices. But in many countries a unique personal identification number either does not exist, or there are legal restrictions to merge across administrative units $^{12}$. For example, in the United States only a few states have linked children's social security numbers, which are used for all labor market and benefits data, to their birth records, and in many states it is actually illegal to link social security numbers to education records. In cases like these, it becomes extremely difficult to link data across administrative data domains. While many states in the United States are making strong progress in linking education and workforce data, thanks to the leadership of the Data Quality Campaign, a national organization dedicated to promoting the development, implementation, and use of high-quality administrative education data sets, and other allied groups, this is a difficult and slow-going process.

Another issue is, of course, that it is hard to follow people moving to other countries since they may change citizenship, or even if people are studying and working abroad it is hard to follow them in terms of income or graduation. Hence, attrition of samples might be an issue. One will be able to identify which country they move to and

\footnotetext{
${ }^{12}$ Another legal restriction was in place, until recently, in Finland where the possibility of indirect identification of individuals in small groups prevented researchers from using registry data in full capacity.
} 
the reason for moving, but not outcomes. This is of course a limitation, but the same limitation is shared by standard surveys. This issue is certainly compounded in countries like the United States where people move freely and often between states but individual states maintain their own birth records, health records, education records, and workforce data. In recent years, it has become possible in rare circumstances to match school records to tax data from the Internal Revenue Service in order to follow children living in one state to adult outcomes in another state (see, e.g., Chetty et al., 2014), and we are hopeful that more cases like that will occur in the future.

Since the administrative data sets are not designed for research in the first place, they are not particularly well-documented (with some exceptions). This also means that there is a big investment aspect of using these data sets as compared to more standard surveys, for instance in the United States some of the surveys are publicly available and very well documented. The larger research groups in the Nordic countries using several matched registers have used the data sets over a long time and spent a considerable amount of resources in checking the data and understanding its structure, the content of the variables, and the changing definitions of these variables over time. Due to changes in tax laws for instance, also the definition of earnings provided in these data sets may change. These changes are not always easily available to outsiders of the administrative units collecting the data. And of course, it is always possible that the administrative data sets are incomplete or have other errors in them, because their purpose was never for research quality but rather for recording activities such as governmental program participation and compliance. As a consequence, these data may not have been subjected to the same type of quality assurance/quality control that is standard in the case of data sets collected specifically for research purposes.

\section{Political issues related to anonymity}

An important issue with using administrative registers is that they cannot be made available publicly, due to security and confidentiality concerns. Given that unique personal identifiers exist, most countries with these data sets have developed secure systems for making them available to researchers or research groups. In the Nordic countries (with the exception of Finland where a slightly different system is in place), 
very similar system have been developed over time where the Statistical agencies play an important role in merging and de-identifying data for researchers, generally through research centers that have been through a quite extensive application procedure with data authorities, owners of data and the national statistical offices.

For all of the Nordic countries there are several research groups with access to the same or very overlapping collection of administrative data sets, and no research group has the "monopoly" to certain registers. The advantage is, of course, that research can be replicated by other researchers. This is true to an increasing degree in a number of other countries, such as the United Kingdom, Chile, the Netherlands, and numerous states in the US, to name a few. Governments must balance the costs associated with potential security breaches against the very large benefits of making data available to a wide range of researchers, who have insights and expertise in a larger set of substantive research issues. It is imperative that researchers work diligently to ensure that they treat administrative data with care and maintain high degree of security so that justifiably worried stewards of administrative data can feel more confident that sharing data with scholars provides high benefits to citizens with extremely low risks of security breaches or other forms of negligent behavior.

\section{$V$. The use of administrative data around the world}

We begin this section by specifying different types of administrative data used in educational research. In tables 1 through 4 we mostly focus on student or teacher registries; however, we also consider principals, pre-formal schooling children and other individuals for whom we observe administrative educational records. These tables are divided by whether the data sets are matched or unmatched to other records, and whether or not they are linked to surveys or experiments. Table 1 lists papers that use a single administrative data source; table 2 lists papers that matches individuals across various administrative data sources; table 3 lists papers that use a single administrative data source which is matched to either survey or experimental data; table 4 lists papers that matches individuals both across various administrative data sources and to either survey or experiment. We group the papers by continent, country, region (state) and provide abbreviated bibliographic information. 
It is not our purpose to provide an encyclopedic review of all papers making use of administrative data around the world, but we wanted to offer a very wide-ranging sampling of the current state of the use of administrative data throughout the world. We therefore sought to systematically survey a large number of leading economics outlets that publish papers in the economics of education. Specifically, we browsed all articles published or accepted for publication between January 1990 and July 2014 in the American Economic Journal: Applied Economics, American Economic Journal: Economic Policy, American Economic Review, Econometrica, Economic Journal, Economics of Education Review, Education Finance and Policy, Journal of Human Resources, Journal of Labor Economics, Journal of Political Economy, Journal of Public Economics, Quarterly Journal of Economics, Review of Economic Studies, and Review of Economics and Statistics, as well as all 2014 NBER Working Papers from the Education program published until the end of July 2014. Although we recognize that this list is far from being comprehensive, we covered 350 papers from 28 countries and all continents except for Antarctica.

In the tables, we organize countries by regions of the world -- Europe, North America, South America, Asia, Africa, and Oceania - and then order all papers within country and state (region) by publication date ${ }^{13}$. It is clear that the majority of research (published in these outlets at least) makes use of data from North America (253 papers), and in particular the United States (240 papers). It is possible that this is a substantial overstatement of the North American share of education economics research using administrative data because of possible publication biases of the journals that we selected for inclusion, but again, our charge is not to be comprehensive in our survey. A large fraction of papers in the list make use of data from Europe (85 papers), while smaller shares makes use of data from South America (18 papers), Africa (6 papers), Asia (4 papers), and Oceania (1 paper). Within Europe the majority of papers come from England, Israel, Norway, and Sweden. These four countries comprise $77 \%$ of European output. Within United States, the majority of research comes from North Carolina, Florida, Texas, Chicago, and New York City; however, nearly half of the States in the Union contributed at least one paper to the list, and given the large investments in data

\footnotetext{
${ }^{13} \mathrm{We}$ treat Israel as part of Europe for our accounting purposes.
} 
infrastructure throughout the United States we expect the geographic spread to continue in the future. That said, it is not an accident that so many papers make use of data from North Carolina, Florida, Texas, Chicago, and New York City, as these are major U.S. jurisdictions that facilitate research more than most. Among other countries Chile contributed 11 papers, while Canada 9. There is also growing output based on Kenyan data. It is also clear from tables 1 to 4 that majority of the research output utilizes only a single administrative data source (e.g. school records) which could be related to both limited data infrastructure and matching restrictions (e.g. in the US). At the same time it is relatively rare that researchers are able to match individuals across multiple administrative data sets, say birth and school records, and also to survey or experiment only 10 out of 350 paper we identified and primarily from outside of the US.

As stated in the introduction, the use of administrative data is a rather new phenomenon and it has been made possible due to the increase in computational power, decrease in storage prices and enhanced cooperation between governmental agencies and researchers all over the world. The first papers from our list were published in Economics of Education Review (Theobald, 1990) and in the Journal of Human Resources (Murnane and Olsen, 1990). The former one used data from Washington, while the latter one from North Carolina, and both papers investigated the role that different variables play in teacher retention. In fact through the 1990s the surveyed journals published only seven papers using administrative data and six of these were studying the teacher labor market. One reason for the focus on teachers in the early use of administrative data is the fact that due to bureaucracy and budgeting the records of public school employees were compiled and stored centrally by state departments of education long before researchers expressed interest in them, while few countries around the world systematically collected student achievement information.

In the 2000s there was a rapid increase in the amount of scientific output using administrative data with 114 papers published in our list. The diversity also increased and papers used not only data on teachers and students but also on individuals pre- and posttheir schooling years. Finally, between 2010 and July 2014 the scientific journals we surveyed have already published nearly 230 papers. This massive increase was driven mostly by the United States, but in every year more and more countries contribute to the 
global "data village". The first papers in our list using European data were published in 2001 using data from Jerusalem, from South America in 2000 using Chilean data, from Asia in 2009 using data from Beijing, and from Africa in 2009 using Kenyan data.

Akin to the examples provided in our Norway, Sweden, and Florida case studies, we observe a substantial variation in the types of registry data used internationally. This depends both on data infrastructure itself but also on the institutional setting in a particular country, state or region under investigation. For example, even though Norway has very high-quality long run data it is difficult to study the long-run effects of school competition in this country because there is no variation in the competitive pressure faced by different schools. Similarly, although Sweden has introduced school competition to its institutional setting and hence it is possible to study whether such policies have long lasting effects, it is actually impossible to look at these effects in a short-run, i.e., in a manner comparable to the United States, because Sweden did not test its pupils using standardized assessments. Yet another problem is the possibility to link different data registers, and from this perspective in most states in the United States it is not possible to study the effects of, for example, neonatal health on schooling outcomes (Table 2). The data simply do not allow a clean match between birth records and school records due to lack of unique personal identifier. Notable exception here is Florida that assigns their newborns social security numbers. Useful but not perfect way around this last problem is widely used in historical research probabilistic matching of individuals (Ferrie and Long, 2013). This method has been applied to some modern data sets like birth and school records in North Carolina (Ladd et al., 2012) but the match rates based on these procedures are not ideal and they are sensitive to the type of populations under scrutiny.

The examples in the paragraph above illustrate the complexity behind research projects involving registry data but also point out to the need of both data infrastructure and credible variation in studying economic and educational phenomena. The agenda becomes even more complex when the research objectives involve long-run effects of particular interventions, their spillovers or understanding the mechanisms through which these interventions operate. In this case population-level administrative registries are particularly essential as these research projects often involve matching subjects in field experiments to themselves decades later (Aslund, et al., 2011) or to subjects' siblings 
(Black et al., 2014). Furthermore, when the goal is to elicit mechanisms through which the policies operate then most often the survey instruments need to be applied to the studied populations and then matched back to the original registers (Burgess et al., forthcoming).

Due to the institutional issues brought up in the paragraphs above researchers in different countries seem to specialize in studying very specific questions based on the registers that are available to them, and the policy environments that they face. Scandinavian countries produce mostly studies that involve rather lower quality educational measures for which they compensate with the fact that individuals can be tracked from their birth to their death and often also across generations ${ }^{14}$. These countries do not have longitudinal student assessment data but are the only locations in the world where the whole population of males undergoes physical, intellectual and emotional evaluations at the time of entering adulthood ${ }^{15}$. On the other side of this spectrum are countries like England or the majority of the U.S. states that have regular student assessments but do not allow merging different databases. A few notable exceptions to that rule are for instance Florida, Texas, Chicago, Charlotte-Mecklenburg (North Carolina), and New York City that allow linking student records to subsequent postsecondary education (Booker et al., 2011), criminal records (Deming, 2011) or labor market outcomes (Clark and Martorell, 2014). These are generally rare because they require agreements and cooperation of multiple governmental agencies ${ }^{16}$. A longitudinal data set that follows kids from birth through childhood, adolescence to adulthood is also available for the province of Manitoba, Canada. These data are somewhat in-between Scandinavian and United States registers because although they allow tracking individuals longitudinally, they do not allow for more complex familial linkages or longitudinal student assessment. There are also few data sets with longitudinal

\footnotetext{
${ }^{14}$ A notable exception here is Finland where research community has not have until recently such a wide access to national registers as in Denmark, Sweden or Norway.

${ }^{15}$ The mandatory military draft has been revoked in Sweden in the mid 2000s but the data for the cohorts 1952 to 2002 can still be used. At the same time as discussed in our case studies Sweden is in the process of rolling out longitudinal student assessments in their compulsory schooling system in grades 3, 6 and 9 .

${ }^{16}$ Note that in Scandinavia, unlike in the US, the multiple registers are handled by a single agency and even though Department of Defense administers the military draft and Department of Education coordinates the $9^{\text {th }}$ grade assessments the research proposal is submitted and processed through a single Data Inspection Authority.
} 
components outside of Scandinavia or North America. For instance, it is possible to link birth records to schooling records in Chile (Bharadwaj, Loken and Neilson, 2013), link birth records to death records to schooling records in Taiwan (Gimenez et al., 2013) or link schooling interventions to long-run outcomes in Israel (Lavy, 2014).

The growth in access to administrative data across the World is crucial from the policy point of view because it allows direct testing of external validity of particular economic phenomena in different institutional setting. In fact we see more and more multi-state or multi-country studies in recent years, e.g. Fryer (2014) or Bharadwaj, Loken and Neilson $(2013)^{17}$. The concern with external validity and ability to study the same policies in multiple locations is the more important in experimental work that necessarily focuses on rather narrow populations, but is becoming a "gold standard" in policy evaluations. The single-country multi-site studies are important from national policy point of view, especially in diverse countries like United States or France, because it is not obvious that intervention which works in Chicago Public Schools or East Paris will work in more affluent areas like Greenwich, Connecticut or Neuilly-sur-Seine. Another broader question is whether similar policies give the same effects in culturally, economically or institutionally different environment. In this case researchers have to rely on rare interventions that are universal across many countries, like for example standardized treatment of low birth weight babies. These studies are extremely valuable because they often allow research community to understand a more fundamental background of human social behavior. They also allow studying externalities of particular policies interacting with different institutional environments.

In the remaining part of this section we focus on particular questions relevant to educational research agenda, and how these have been addressed in different countries or states. We start off with the fundamental question of how early childhood environment affects educational, and potentially long-run outcomes. Given the advantages and disadvantages of various administrative data sets described in the paragraphs above, it is not surprising that this research question has been dominated by studies based on

\footnotetext{
${ }^{17}$ There is fewer published cross-country than cross-state studies, however, we should see more and more of the former ones coming in the next few years. Another notable example is study of Bedard and Dhuey (2006) which combines results from Canada based on administrative data and from other countries based on various survey data.
} 
Scandinavian data (Table 2). The excellent data infrastructure in Denmark, Sweden and Norway allows tracking individuals not only from their birth to their death but also across multiple generations and familial connections as children are linked to their biological parents using unique identifiers, and the parents are in turn linked to their siblings using unique identifiers. Except for the three aforementioned Scandinavian countries early childhood has also been studied in two other European countries: England (Almond, Mazumder and Van Ewijk, 2014) and Germany (Dustmann and Schonberg, 2012). In North America we have a birth order study from Indiana (Hanushek, 1992) which is the only study from the 1990s on our list that was not focused specifically on teachers but used an experimental population from Gary Income Maintenance Experiment merged to children schooling records. The other papers include birth weight effects estimates from Canada (Oreopoulos et al., 2008) and Florida (Figlio et al., 2014), in-utero pollution exposure study from Texas (Sanders, 2012) and an influential foster care system evaluation from Illinois (Doyle, 2007). A paper from Taiwan investigates the effects of parental loss on children's well-being (Gimenez et al., 2013) while a paper based on Chilean and Norwegian data studies the role of health interventions at birth (Bharadwaj, Loken and Neilson, 2013). Some of these papers, due to their use of administrative data, documented new and important empirical phenomena. Figlio et al. (2014) are among the first to document that neonatal health and parental socioeconomic status are likely complements rather than substitutes - a common perception was rather that wealthier parents can better compensate for lower health capital of their children than poorer parents. Bharadwaj, Lokean and Neilson (2013) show that health interventions in countries as different as Chile and Norway can yield fairly similar effects which boosts the confidence that earl life interventions effectiveness is not necessarily tied to specific institutional environment or wealth of the society.

Across different countries and institutional settings the most often studied question seems to be the role of school technology or the education production function. These topics range from the questions of how gender composition of classrooms influences female school choice in Austria (Schneeweis and Zweimuller, 2012), or how ethnic and immigrant concentration in schools affects cognitive development of children 
in Denamrk (Jensen and Rasmussen, 2011) ${ }^{18}$ and England (Dustmann, Machin and Schonberg, 2010), through mandatory school entry and exit ages in Germany (Muhlenweg and Puhani, 2010) and the Netherlands (Cabus and De Witte, 2011) to school resources in Norway (Haegeland, Raaum and Salvanes, 2012), Canada (Leach, Payne and Chan, 2010) and New York City (Rubenstein et al., 2009). There is also a substantial variation in the kind of inputs that are investigated in different states within the Union. They span from the role of the quantity of math instruction hours in Florida (Taylor, 2014) through teacher cheating in Chicago (Jacob and Levitt, 2003) to the role of school crowding in North Carolina (McMullen and Rouse, 2012) or paying students for grade completion in Ohio (Bettinger, 2012).

There are also multi-site studies within the US that explore the role of same school inputs in very different school environments, and thus, allow for assessment of generalizability of the interventions. An example of such study would be Fryer's (2014) investigation of the role of importing best charter school practices to traditional public schools in Chicago, Denver and Houston. His results are remarkably similar across Denver and Houston, the two experimental samples, and are smaller for Chicago, where only quasi-experimental variation is available. Notably Denver and Houston differ both in terms of demographics and institutional setting so the similarity of the estimates is noteworthy. It is also the case that Chicago implemented a slightly less intensive program which could account for the difference in the effects. Another example of this kind of cross-sites within-country research is Abdulkadiroglu, Angrist and Pathak (2014) who investigate the role of school composition on student achievement in Boston and New York. In both cities they find little evidence that attending elite schools has a causal effect on test scores or college quality. Similar findings are confirmed in Kenyan setting (Lucas and Mbiti, 2014) but Jackson (2010) finds large gains from attending elite schools in Trinidad and Tobago. This set of papers unlike the health interventions at birth suggests

\footnotetext{
${ }^{18}$ The Danish study is the more important because it merges PISA data with registry data which in a longer-run will allow benchmarking the PISA test scores against economically meaningful variables like university graduation or income. Since PISA is used globally to compare the efficiency of educational systems it seems imperative to understand how PISA scores translate into long-run outcomes. To our knowledge Denmark is the only country that successfully merged their PISA samples to administrative records.
} 
that some educational policies might be generalizable with country but not across countires.

One particular school attribute that gained a lot of attention in the educational research agenda involves class size (Angrist and Lavy, 1999; Chetty et al. 2011). Neither of these two papers used administrative educational data sets, but there exists evidence on this topic from at least four countries and two states using educational administrative data. This question has been studied in Denmark (Heinesen, 2010), Italy (Angrist, Battisin and Vuri, 2014), Sweden (Fredriksson, Ockert and Oosterbeek, 2013), and in the United States in Florida (Chingos, 2012). Using different identification strategies and data these papers generally find conflating results. Danish, Italian and Swedish studies confirm the previous results based on survey data that smaller classes generate significant advantages in later life schooling and labor market outcomes. On the contrary the Florida case-study and also another paper using Norwegian registry data (Leuven, Oosterbeek and Ronning, 2008) do not find much of an effect of a reduction in class size. It is particularly interesting that the Swedish and Norwegian studies use an identical identification strategy but find very different results. This point makes clear the value of cross-context replication and studies.

The two remaining studies of class size in our list are somewhat different. Complementary research from Kentucky (Barrett and Toma, 2013) documents that principals are more likely to assign more effective teachers to larger classes, potentially to compensate for the negative class-size effects. Finally, a Chilean (Urquiola and Verhoogen, 2009) paper makes a more methodological point by documenting an inverted-U cross-sectional relationship between class-size and household income as well as stacking of schools' enrollments at multiples of the class-size cap. These two data facts could invalidate non-experimental or regression discontinuity estimates of the class-size in liberalized market settings where schools are free to set prices and/or turn away students, and households are free to sort between schools. The manipulation of a classsize rule that can potentially invalidate the regression discontinuity estimates has also been documented in Israel (Cohen-Zada, Gradstein and Reuven, 2013). Comprehensive administrative data facilitated these studies that otherwise would be harder to conduct. 
Another hotly debated in the past decades educational policy topic has been the role of school choice and competition. Around the world, governments have recently implemented and researchers evaluated various forms of choice and competition. Outside the United States the countries that contributed to this broad research agenda are England, Israel, and Sweden in Europe, Canada and United States in North America, Colombia and Chile in South America, and China in Asia. However, not all of these countries study the same phenomena that we encapsulate in a single broad term of school choice. For example, outside the United States, the effects of voucher and charter schools on student outcomes are examined in England (Clark, 2009), Sweden (Sandstrom and Bergstrom, 2005), Chile (Mizala and Romaguera, 2000) and Colombia (Angrist, Bettinger and Kremer, 2006; Bettinger, Kremer and Saavedra, 2010). These papers, with the exception of early Chilean descriptive work, point towards beneficial effects of vouchers on student achievement. An interesting modification of the voucher system type of competition is studied in Ontario, Canada (Card, Dooley and Payne, 2010) where non-Catholics are subject to monopoly of public schools while Catholics ( $40 \%$ of children in the province) can choose between sending their kids to secular public schools or to separate schools. The authors also find test score gains due to increased competition in Ontario.

These effects have also been investigated in the United States for Florida (Figlio and Hart, 2014), Chicago (Booker et al., 2011), Massachusetts (Angrist, Pathak and Walters, 2013), New York City (Winters, 2012), Texas (Booker et al., 2007) and Utah (Ni and Rorrer, 2012). The results generally suggest heterogeneous effects of charters which might be either due to the fact that they apply different identification strategies or due to differential role of institutional settings. Research by Zimmer et al. (2012) examines the role of charter schools more comprehensively by looking simultaneously at seven states but it is important to note that their analysis is based on individual fixed effects and not on random or quasi-random variation. They find mixed results for charter school effects and point out that their results rely heavily on the assumptions they make along the way. This study with such an external validity would not be possible without administrative data available in multiple sites within the US. There is also research that considers lotteries and open enrollment to schools that are not necessarily private schools. Cullen, Jacob and Levitt (2006) find little evidence for improvements of achievement of 
lottery winners in Chicago, while Deming et al. (2014) find increases in college attainment among lottery winners in Charlotte-Mecklenburg. Free school choice seems to also benefit students in Israel (Lavy, 2010). Clearly, more work is needed in order to gauge the degree to which specific programs and identification strategies are responsible for differing research findings.

Another strand of this agenda considers the role of parents in school choice in England (Burgess et al., forthcoming), Beijing (Lai, Sadoulet and de Janvry, 2009) and Charlotte-Mecklenburg (Hastings and Weinstein, 2008). There is also research that considers the importance of accurate information on school quality when school choice is available in England (Allen and Burgess, 2013); and that examines the potential negative spillovers from school choice, like grade inflation in Sweden (Wikstrom and Wikstrom, 2005). Finally, competition and school choice may affect not only students but also their teachers, and we discuss this research agenda below where we focus more broadly on the labor market for teachers.

Much of the early research using administrative data focused on the labor market for teachers but the interest in this topic did not decline over time. In fact other countries and states started contributing papers studying teachers. In the United States we observe researchers in a large number of states investigating the labor market for teachers; specific examples include the use of administrative data in Alaska, Arkansas, Colorado, Florida, Illinois, Georgia, Kentucky, Michigan, Missouri, North Carolina, New York, Ohio, Pennsylvania, Texas, Washington, and Wisconsin. Outside of the United States teachers have been studied in Israel, Italy, Norway, Sweden, and Venezuela. The most widely studied question is likely the teacher labor supply and mobility that has been investigated within the United States in Florida (Feng, 2010), Georgia (Scafidi, Sjoquist and Stinebrickner, 2007), Kentucky (Cowen et al., 2012), Michigan (Gershenson, 2012), Missouri (Podgursky, Monroe and Watson, 2004), North Carolina (Jackson, 2013), New York (Brewer, 1996), Texas (Hanushek, Kain and Rivkin, 2004), Washington (Theobald, 1990), Wisconsin (Imezeki, 2005); and internationally in Italy (Barbieri, Rossetti and Sestito, 2011), Norway (Falch and Strom, 2005), Sweden (Karbownik, 2014) and 
Venezuela (Ortega, 2010) ${ }^{19}$. The broad conclusion from these papers is that school quality and working conditions matter for attracting and retaining teachers, particularly those of higher quality, but particular factors differ across sites in both whether they matter and how much they matter.

Another related topic that is present only in the United States research, to the best of our knowledge, is the role of teacher retirement and the retirement benefits. This particular question has been studied in Arkansas (Costrell and McGee, 2010), Illinois (Fitzpatrick and Lovenheim, 2014), Missouri (Koedel, Ni and Podgursky, 2014), Pennsylvania (Ferguson, Strauss and Vogt, 2006) and Washington (DeArmond and Goldhaber, 2010). Some other studies consider the role of incentives in improving teacher performance in Denver (Goldhaber and Walch, 2012), Chicago (Jacob, 2013), Kentucky (Barrett and Toma, 2013), New York City (Fryer, 2013), Houston (Imberman and Lovenheim, 2015) and outside of the US in Israel (Lavy, 2009).

A lot of attention in the United States has also been given to the interaction between the schools, teachers and their students. School accountability was introduced voluntarily by many states in the 1990s but with the introduction of the federal No Child Left Behind law in 2002 the remaining states were required to start measuring the relative performance of their students, which by extension allowed calculations of value added measures, assessment of teacher effectiveness and as an unintended side-effect produced large quantities of administrative data on teacher and their students (Figlio and Loeb, 2011). Based on our selection of journals we found value added or accountability research from San Diego (Koedel and Betts, 2010), Colorado (Briggs and Weeks, 2009), Florida (Sass, Semykina and Harris, 2014), Chicago (Aaronson, Barrow and Sander, 2007), North Carolina (Rothstein, 2010), Texas (Rivkin, Hanushek and Kain, 2005), and Washington (Krieg, 2011). Outside of the United States, value added models have also been examined in two other English speaking countries, mainly England (Ray, McCormack and Evans, 2009) and Australia (Leigh, 2010).

There are many other research themes that we did not cover in this brief review and which gained considerable attention in the research community. To name a few from

\footnotetext{
${ }^{19}$ Many of these states and countries contributed multiple studies on the topic of teacher labor supply and mobility.
} 
our extensive but incomplete list, registry data have been used to study: the introduction of new technologies to schools in England (Machin, McNally and Silva, 2007), experimental evidence on schools influence on parents' involvement in education in France (Avvisati et al., 2014), experimental evidence on gender differences in competitiveness and its consequences for educational choices in the Netherlands (Buser, Niederle and Oosterbeek, 2014), the role of school quality in Romania (Pop-Elches and Urquiola, 2013), experimental evidence on learning incentives in Mexico (Behrman et al., 2015), perceived effects of school quality on housing market (Figlio and Lucas, 2004), the role of peer effects utilizing student reshuffling due to extreme events (Imberman, Kugler and Sacerdote, 2012) or the ability of principals to recognize effective teachers (Jacob and Lefgren, 2008). We also have not mentioned some unique educational data sets used worldwide to address very specific research questions. These would be GED takers in Florida and Texas (Tyler, Murnane and Willett, 2004), principals in Illinois and North Carolina (Gates et al., 2006), college entry exam takers in Michigan (Andrews, DesJardins and Ranchhod, 2010) or anthropometric measurements of school children in Peru (Dell, 2010).

In summary, there is a growing prevalence in the use of administrative data in educational research and in this section we hoped to provide some brief overview of this phenomenon internationally. We did not and could not aim to be complete here, however, our goal was to provide useful examples of applications and data types utilized in different countries. It is clear that there are many opportunities to study new questions in new environments, and we expect that the explosion in the use of administrative data in education research will only continue to expand rapidly.

\section{Conclusions}

It is evident that administrative data present a world of opportunity, and while there are clearly challenges associated with the use of administrative data, the benefits of collecting these data and using them for research and policy purposes surely outweigh the costs involved. While administrative data are not a substitute for many purpose-built survey data, in the cases in which they are substitutes they have the potential to save taxpayers considerable amounts of money while delivering better-quality data, and of 
course there are many ways in which administrative data can make survey data better, more cost-effective, and more flexible. The availability of these data has led to new research questions that had previously not been addressable being studied; the overturning of conventional wisdom through higher-quality research designs made possible by better data; and more data-driven policymaking in education. All of these are victories for both research and policy. Given the remarkable progress of computing power and capacity, it is in the best interest of both science and policy to make good use of these administratively-collected data while following best practices in data security and ethics. Furthering partnerships and trust relationships between the entities that collect and administer these administrative data and members of the scholarly community, and developing de-identified data sets that will protect privacy and confidentiality while furthering research will benefit taxpayers, policy makers and scholars alike.

\section{References}

Aaronson, D., Barrow, L., Sander, W., 2007. Teachers and Student Achievement in the Chicago Public High Schools. J. Labor Econ. 25 (1), 95-135.

Abdulkadiroglu, A., Pathak, P.A., Roth, A.E., 2009. Strategy-Proofness versus Efficiency in Matching with Indifferences: Redesigning the NYC High School Match. Am. Econ. Rev. 99 (5), 1954-1978.

Abdulkadiroglu, A., Angrist, J.D., Dynarski, S.M., Kane, T.J., Pathak, P.A., 2011. Accountability and Flexibility in Public Schools: Evidence from Boston's Charters and Pilots. Q. J. Econ. 126 (2), 699-748.

Abdulkadiroglu, A., Angrist, J., Pathak, P., 2014. The Elite Illusion: Achievement Effects at Boston and New York Exam Schools. Econometrica 82 (1), 137-196.

Ahn, T., 2014. A Regression Discontinuity Analysis of Graduation Standards and Their Impact on Students' Academic Trajectories. Econ. Educ. Rev. 38, 64-75.

Ahn, T., Vigdor, J.L., 2014. When Incentives Matter Too Much: Explaining Significant Responses to Irrelevant Information. NBER Working Paper No. 20321.

Allen, R., Burgess, S., 2013. Evaluating the Provision of School Performance Information for School Choice. Econ. Educ. Rev. 34, 175-190.

Almaas, I., Cappelen, A., Salvanes, K.G., Sorensen, E., and Tungodden, B. 2014. Willingness to Compete: Family Matters. NHH Discussion Paper 3/2014. 
Almond, D., Edlund, L., Palme, M., 2009. Chernobyl's Subclinical Legacy: Prenatal Exposure to Radioactive Fallout and School Outcomes in Sweden. Q. J. Econ. 124 (4), 1729-1772.

Almond, D., Mazumder, B., van Ewijk, R., 2014. In Utero Ramadan Exposure and Children's Academic Performance. forthcoming Econ. J.

Anand, P., Mizala, A., Repetto, A., 2009. Using School Scholarships to Estimate the Effect of Private Education on the Academic Achievement of Low-Income Students in Chile. Econ. Educ. Rev. 28 (3), 370-381.

Andersson, C., Johansson, P., Waldenstrom, N., 2011. Do You Want Your Child to Have a Certified Teacher? Econ. Educ. Rev. 30 (1), 65-78.

Andrews, R.J., DesJardins, S., Ranchhod, V., 2010. The Effects of the Kalamazoo Promise on College Choice. Econ. Educ. Rev. 29 (5), 722-737.

Angrist, J.D., Lavy, V., 2001. Does Teacher Training Affect Pupil Learning? Evidence from Matched Comparisons in Jerusalem Public Schools. J. Labor Econ. 19 (2), 343-369.

Angrist, J.D., Lang, K., 2004. Does School Integration Generate Peer Effects? Evidence from Boston's Metco Program. Am. Econ. Rev. 94 (5), 1613-1634.

Angrist, J., Bettinger, E., Kremer, M., 2006. Long-Term Educational Consequences of Secondary School Vouchers: Evidence from Administrative Records in Colombia. Am. Econ. Rev. 96 (3), 847-862.

Angrist, J., Lavy, V., 2009. The Effects of High Stakes High School Achievement Awards: Evidence from a Randomized Trial. Am. Econ. Rev. 99 (4), 1384-1414.

Angrist, J.D., Pathak, P.A., Walters, C.R., 2013. Explaining Charter School Effectiveness. Am. Econ. J. - Appl. Econ. 5 (4), 1-27.

Angrist, J.D., Battistin, E., Vuri, D., 2014. Is a Small Moment: Class Size and Moral Hazard in the Mezzogiorno. NBER Worping Paper No. 20173.

Apps, P., Mendolina, S., Walker, I., 2013. The Impact of Pre-School on Adolescents' Outcomes: Evidence from a Recent English Cohort. Econ. Educ. Rev. 37, 183-199.

Arteaga, I., Humpage, S., Reynolds, A.J., Temple, J.A., 2014. One Year of Preschool or Two: Is It Important for Adult Outcomes? Econ. Educ. Rev. 40, 221-237.

Aslund, O., Edin, P-A., Fredriksson, P., Gronqvist, H., 2011. Peers, Neighborhoods, and Immigrant Student Achievement: Evidence from a Placement Policy. Am. Econ. J. Appl. Econ. 3 (2), 67-95.

Avvisati, F., Guragand, M., Guyon, N., Maurin, E., 2014. Getting Parents Involved: A Field Experiment in Deprived Schools. Rev. Econ. Stud. 81 (1), 57-83. 
Barbieri, G., Rossetti, C., Sestito, P., 2011. The Determinants of Teacher Mobility: Evidence Using Italian Teachers' Transfer Applications. Econ. Educ. Rev. 30 (6), 14301444.

Barrera-Osorio, F., Bertrand, M., Linden, L.L., 2011. Improving the Design of Conditional Transfer Programs: Evidence from a Randomized Education Experiment in Colombia. Am. Econ. J. - Appl. Econ. 3 (2), 167-195.

Barrett, N., Toma, E.F., 2013. Reward or Punishment? Class Size and Teacher Quality. Econ. Educ. Rev. 35, 41-52.

Barrow, L., Markman, L., Rouse, C.E., 2009. Technology's Edge: The Educational Benefits of Computer-Aided Instruction. Am. Econ. J. - Econ. Policy 1 (1), 52-74.

Bastian, K.C., Henry, G.T., Thompson, C.L., 2013. Incorporating Access to More Effective Teachers into Assessments of Educational Resource Equity. Educ. Financ. Policy. 8 (4), 560-580.

Bedard, K., Dhuey, E., 2006. The Persistence of Early Childhood Maturity: International Evidence of Long-Run Age Effects. Q. J. Econ. 121 (4), 1437-1472.

Behrman, J.R., Parker, S.W., Todd, P.E., Wolpin, K.I., 2015. Aligning Learning Incentives of Students and Teachers: Results from a Social Experiment in Mexican High Schools. J. Polit. Econ. 123(2), 325-264.

Belfield, C.R., Levin, H.M, 2004. Should High School Economics Courses Be Compulsory? Econ. Educ. Rev. 23 (4), 351-360.

Bellei, C., 2009. Does Lengthening the School Day Increase Students' Academic Achievement? Results from a Natural Experiment in Chile. Econ. Educ. Rev. 28 (5), 629640.

Bettinger, E., Kremer, M., Saavedra, J.E., 2010. Are Educational Vouchers Only Redistributive? Econ. J. 120 (546), F204-F228.

Bettinger, E, 2012. Paying to Learn: The Effect of Financial Incentives on Elementary School Test Scores. Rev. Econ. Stat. 94 (3), 686-698.

Bettinger, E., Haegeland, T, Rege, M., 2014. Home with Mom: The Effects of Stay-atHome Parents on Children's Long-Run Educational Outcomes. J. Labor Econ. 32 (3), 443-467.

Beuermann, D.W., Cristia, J., Cueto, S., Malamud, O., Cruz-Aguayo, Y., 2014. One Laptop per Child at Home: Short-Term Impacts from a Randomized Experiment in Peru. Am. Econ. J. - Appl. Econ. 7(2), 53-80. 
Bharadwaj, P., Loken, K.V., Neilson, C., 2013. Early Life Health Interventions and Academic Achievement. Am. Econ. Rev. 103 (5), 1862-1891.

Bifulco, R., Ladd, H.F., 2006. The Impacts of Charter Schools on Student Achievement: Evidence from North Carolina. Educ. Financ. Policy. 1 (1), 50-90.

Billings, S.B, Deming, D.J, Rockoff, J, 2014. School Segregation, Educational Attainment, and Crime: Evidence from the End of Busing in Charlotte-Mecklenburg. Q. J. Econ. 129 (1), 435-476.

Bjorklund, A., Lindahl, M., Plug, E., 2006. The Origins of Intergenerational Associations: Lessons from Swedish Adoption Data. Q. J. Econ. 121 (3), 999-1028.

Bjorklund, A., Salvanes, K.G., 2011. Education and Family Background: Mechanisms and Policies. Handbook of Economics of Education 3, 201-247.

Black, S.E., Devereux, P.J., Salvanes, K.G., 2005a. Why the Apple Doesn't Fall Far: Understanding Intergenerational Transmission of Human Capital. Am. Econ. Rev. 95 (1), 437-449.

Black, S.E., Devereux, P.J., Salvanes, K.G., 2005b. The More the Merrier? The Effect of Family Size and Birth Order on Children's Education. Q. J. Econ. 120 (2), 669-700.

Black, S.E., Devereux, P.J., Salvanes, K.G., 2007. From the Cradle to the Labor Market? The Effect of Birth Weight on Adult Outcomes. Q. J. Econ. 122 (1), 409-439.

Black, S.E., Devereux, P.J., Salvanes, K.G., 2010. Small Family, Smart Family? Family Size and the IQ Scores of Young Men. J. Hum. Resour. 45 (1), 33-58.

Black, S.E., Devereux, P.J., Salvanes, K.G., 2011. Too Young to Leave the Nest? The Effects of School Starting Age. Rev. Econ. Stat. 93 (2), 455-467.

Black, S.E., Devereux, P.J., Salvanes, K.G., 2013. Under Pressure? The Effect of Peers on Outcomes of Young Adults. J. Labor Econ. 31 (1), 119-153.

Black, S.E., Devereux, P.J., Loken, K.V., Salvanes, K.G., 2014. Care or Cash? The Effect of Child Care Subsidies on Student Performance. Rev. Econ. Stat. 96(5), 824-837.

Black, S.E., Devereux, P.J., Salvanes, K.G., 2014. Does Grief Transfer Across Generations? In-Utero Deaths and Child Outcomes. NBER Working Paper No. 19979.

Black, S.E., Figlio, D.N., Guryan, J.G., Karbownik, K., Roth, J., 2014. The Educational Consequences of Having a Disabled Sibling. Mimeo

Blimpo, M.P., 2014. Team Incentives for Education in Developing Counties: A Randomized Field Experiment in Benin. Am. Econ. J. - Appl. Econ. 6(4), 90-109. 
Bohlmark, A., Gronqvist, E., Vlachos, J., 2012. The Headmaster Ritual: The Importance of Management for School Outcomes. IFAU Working Paper 2012:16.

Bohlmark, A., Lindahl, M., 2015. Independent Schools and Long-Run Educational Outcomes - Evidence from Sweden's Large Scale Voucher Reform. Economica. 82(327), 508-551.

Booker, K., Gilpatric, S.M., Gronberg, T., Jansen, D., 2007. The Impact of Charter School Attendance on Student Performance. J. Public Econ. 91, 849-876.

Booker, K., Sass, T.R., Gill, B., Zimmer, R., 2011. The Effects of Charter High Schools on Educational Attainment. J. Labor Econ. 29 (2), 377-415

Boyd, D., Grossman, P., Lankford, H., Loeb, S., Wyckoff, J., 2006. How Changes in Entry Requirements Alter the Teacher Workforce and Affect Student Achievement. Educ. Financ. Policy. 1 (2), 176-216.

Boyd, D., Grossman, P., Ing, M., Lankford, H., Loeb, S., O’Brien, R., Wyckoff, J., 2011. The Effectiveness and Retention of Teachers with Prior Career Experience. Econ. Educ. Rev. 30 (6), 1229-1241.

Boyd, D., Lankford, H., Loeb, S., Wyckoff, J., 2013. Analyzing the Determinants of the Matching of Public School Teachers to Jobs: Disentangling the Preferences of Teachers and Employers. J. Labor Econ. 31 (1), 83-117.

Brewer, D.J., 1996. Career Paths and Quit Decisions: Evidence from Teaching. J. Labor Econ. 14 (2), 313-339.

Briggs, D.C., Weeks, J.P., 2009. The Sensitivity of Value-Added Modeling to the Creation of a Vertical Score Scale. Educ. Financ. Policy. 4 (4), 384-414.

Brummet, Q., 2014. The Effects of School Closings on Student Achievement. J. Public Econ. 119, 108-124.

Bui, S.A., Craig, S.G., Imberman, S.A., 2014. Is Gifted Education a Bright Idea? Assessing the Impact of Gifted and Talented Programs on Students. Am. Econ. J. - Econ. Policy 6 (3), 30-62.

Burgess, S., Briggs, A., 2010. School Assignment, School Choice and Social Mobility. Econ. Educ. Rev. 29 (4), 639-649.

Burgess, S., Greaves, E., 2013. Test Scores, Subjective Assessment, and Stereotyping of Ethnic Minorities. J. Labor Econ. 31 (3), 535-576.

Burgess, S., Wilson, D., Worth, J., 2013. A Natural Experiment in School Accountability: The Impact of School Performance Information on Pupil Progress. J. Public Econ. 106, 57-67. 
Burgess, S., Greaves, E., Vignoles, A., Wilson, D., 2014. What Parents Want: School Preferences and School Choice. forthcoming Econ. J.

Burke, M.A., Sass, T.R., 2013. Classroom Peer Effects and Student Achievement. J. Labor Econ. 31 (1), 51-82.

Buser, T., Niederle, M., Oosterbeek, H., 2014. Gender, Competitiveness, and Career Choices. Q. J. Econ. 129(3), 1409-1447.

Cabus, S.J., De Witte, K., 2011. Does School Time Matter?-On the Impact of Compulsory Education Age on School Dropout. Econ. Educ. Rev. 30 (6), 1384-1398.

Card, D., Chetty, R., Feldstein, M., Saez, E., 2010. Expanding Access to Administrative Data for Research in the United States. White paper, National Science Foundation, Washington, DC.

Card, D., Dooley, M.D., Payne, A., 2010. School Competition and Efficiency with Publicly Funded Catholic Schools. Am. Econ. J. - Appl. Econ. 2 (4), 150-176.

Carneiro, P., Loken, K., Salvanes, K.G., 2014. A Flying Start? Long Term Consequences of Maternal Time Investments in Children during the First Year of Life. forthcoming J. Polit. Econ.

Carneiro, P., K., Salvanes, K.G., and Tominey, E. 2014. Intergenerational Transmission, Human Capital Formation and the Timing of Parental Income. Working paper, Norwegian School of Economics.

Carrell, S.E., Hoekstra, M.L., 2010. Externalities in the Classroom: How Children Exposed to Domestic Violence Affect Everyone's Kids. Am. Econ. J. - Appl. Econ. 2 (1), 211-228.

Carruthers, C.K., 2012. The Qualifications and Classroom Performance of Teachers Moving to Charter Schools. Educ. Financ. Policy. 7 (3), 233-268.

Carruthers, C.K., 2012. New Schools, New Students, New Teachers: Evaluating the Effectiveness of Charter Schools. Econ. Educ. Rev. 31 (2), 280-292.

Chetty, R., Friedman, J.N., Rockoff, J.E., 2014. Measuring the Impacts of Teachers I: Evaluating Bias in Teacher Value-Added Estimates. Am. Econ. Rev. 104(9), 2593-2632.

Chetty, R., Friedman, J.N., Rockoff, J.E., 2014. Measuring the Impacts of Teachers II: Teacher Value-Added and Student Outcomes in Adulthood. Am. Econ. Rev. 104(9), 2633-2679.

Chiang, H., 2009. How Accountability Pressure on Failing Schools Affects Student Achievement. J. Public Econ. 93, 1045-1057. 
Chingos, M.M, West, M.R., 2011. Promotion and Reassignment in Public School Districts: How Do Schools Respond to Differences in Teacher Effectiveness? Econ. Educ. Rev. 30 (3), 419-433.

Chingos, M.M, Peterson, P.E, 2011. It's Easier to Pick a Good Teacher Than to Train One: Familiar and New Results on the Correlates of Teacher Effectiveness. Econ. Educ. Rev. 30 (3), 449-465.

Chingos, M.M., West, M.R., 2012. Do More Effective Teachers Earn More Outside the Classroom? Educ. Financ. Policy. 7 (1), 8-43.

Chingos, M.M., 2012. The Impact of a Universal Class-Size Reduction Policy: Evidence from Florida's Statewide Mandate. Econ. Educ. Rev. 31 (5), 543-562.

Cho, R.M., 2009. The Impact of Maternal Imprisonment on Children's Educational Achievement: Results from Children in Chicago Public Schools. J. Hum. Resour. 44 (3), 772-797.

Clark, D., 2009. The Performance and Competitive Effects of School Autonomy. J. Polit. Econ. 117 (4), 745-783.

Clark, D., See, E., 2011. The Impact of Tougher Education Standards: Evidence from Florida. Econ. Educ. Rev. 30 (6), 1123-1135.

Clark, D., Martorell, P., 2014. The Signaling Value of a High School Diploma. J. Polit. Econ. 122 (2), 282-318.

Clark, M., Rothstein, J., Schanzenbach, D.W., 2009. Selection Bias in College Admissions Test Scores. Econ. Educ. Rev. 28 (3), 295-307.

Clotfelter, C.T., Ladd, H.F., Vigdor, J., 2005. Who Teaches Whom? Race and the Distribution of Novice Teachers. Econ. Educ. Rev. 24 (4), 377-392.

Clotfelter, C.T., Ladd, H.F., Vigdor, J.L., 2006. Teacher-Student Matching and the Assessment of Teacher Effectiveness. J. Hum. Resour. 41 (4), 778-820.

Clotfelter, C.T., Ladd, H.F., Vigdor, J.L., 2007. Teacher Credentials and Student Achievement: Longitudinal Analysis with Student Fixed Effects. Econ. Educ. Rev. 26 (6), 673-682.

Clotfelter, C.T., Glennie, E., Hall, H., Vigdor, J., 2008. Would Higher Salaries Keep Teachers in High-Poverty Schools? Evidence from a Policy Intervention in North Carolina. J. Public Econ. 92, 1352-1370.

Clotfelter, C.T., Ladd, H.F., Vigdor, J.L., 2009. The Academic Achievement Gap in Grades 3 To 8. Rev. Econ. Stat. 91 (2), 398-419. 
Clotfelter, C.T., Ladd, H.F., Vigdor, J.L., 2009. Teacher Credentials and Student Achievement in High School: A Cross-Subject Analysis with Student Fixed Effects. J. Hum. Resour. 45 (3), 655-681.

Clotfelter, C.T., Ladd, H.F., Vigdor, J.L., 2009. Are Teacher Absences Worth Worrying about in the United States? Educ. Financ. Policy. 4 (2), 115-149.

Clotfelter, C.T., Ladd, H.F., Vigdor, J.L., 2011. Teacher Mobility, School Segregation, and Pay-Based Policies to Level the Playing Field. Educ. Financ. Policy. 6 (3), 399-438.

Coelli, M., Green, D.A., 2012. Leadership Effects: School Principals and Student Outcomes. Econ. Educ. Rev. 31 (1), 92-109.

Cohen-Zada, D., Gradstein, M., Reuven, E., 2013. Allocation of Students in Public Schools: Theory and New Evidence. Econ. Educ. Rev. 34, 96-106.

Condie, S., Lefgren, L., Sims, D., 2014. Teacher Heterogeneity, Value-Added and Education Policy. Econ. Educ. Rev. 40, 76-92.

Cook, P.J., Dodge, K., Farkas, G., Fryer, R.G., Guryan, J., Ludwig, J., Mayer, S., Pollack, H., Steinberg, L., 2014. The (Surprising) Efficacy of Academic and Behavioral Intervention with Disadvantaged Youth: Results from a Randomized Experiment in Chicago. NBER Working Paper No. 19862.

Cortes, K.E., Moussa, W.S., Weinstein, J.M., 2013. Educating Bright Students in Urban Schools. Econ. Educ. Rev. 37, 286-297.

Cortes, K., Goodman, J., Nomi, T., 2014. Intensive Math Instruction and Educational Attainment: Long-Run Impacts of Double-Dose Algebra. NBER Working Paper No. 20211.

Costrell, R.M., McGee, J.B., 2010. Teacher Pension Incentives, Retirement Behavior, and Potential for Reform in Arkansas. Educ. Financ. Policy. 5 (4), 492-518.

Costrell, R.M., Podgursky, M., 2010. Distribution of Benefits in Teacher Retirement Systems and Their Implications for Mobility. Educ. Financ. Policy. 5 (4), 519-557.

Cowen, J.M., Butler, J.S., Fowles, J., Streams, M.E., Toma, E.F., 2012. Teacher Retention in Appalachian Schools: Evidence from Kentucky. Econ. Educ. Rev. 31 (4), 431-441.

Cowen, J.M, Winter, M.A, 2013. Do Charters Retain Teachers Differently? Evidence from Elementary Schools in Florida. Educ. Financ. Policy. 8 (1), 14-42.

Cratty, D., 2012. Potential for Significant Reductions in Dropout Rates: Analysis of an Entire 3rd Grade State Cohort. Econ. Educ. Rev. 31 (5), 644-662. 
Cullen, J.B., Jacob, B.A., Levitt, S.D., 2005. The Impact of School Choice on Student Outcomes: An Analysis of the Chicago Public Schools. J. Public Econ. 89, 729-760.

Cullen, J.B., Jacog, B.A., Levitt, S., 2006. The Effect of School Choice on Participants: Evidence from Randomized Lotteries. Econometrica 74 (5), 1191-1230.

Cullen, J.B., Long, M.C., Reback, R., 2013. Jockeying for Position: Strategic High School Choice under Texas' Top Ten Percent Plan. J. Public Econ. 97, 32-48.

Currie, J., Hanushek, E.A., Kahn, M.E., Neidell, M., Rivkin, S.G., 2009. Does Pollution Increase School Absences? Rev. Econ. Stat. 91 (4), 682-694.

Currie, J., Stabile, M., Manivong, P., Roos, L.L., 2010. Child Health and Young Adult Outcomes. J. Hum. Resour. 45 (3), 517-548.

Currie, J., Figlio, D., Goodman, J., Presico, C., Roth, J., 2014. A Population Level Study of the Effects of Early Intervention for Autism. Mimeo

Curto, V.E., Fryer, R.G., 2014. The Potential of Urban Boarding Schools for the Poor: Evidence from SEED. J. Labor Econ. 32 (1), 65-93.

Dalsgaard, S., Nielsen, H.S., Simonsen, M., 2014. Consequences of ADHD Medication Use for Children's Outcomes. J. Health Econ. 37, 137-151

Damm, A.P., Dustman C., 2014. Does Growing Up in a High Crime Neighborhood Affect Youth Criminal Behavior? Am. Econ. Rev. 104 (6), 1806-1832.

DeArmond, M., Goldhaber, D., 2010. Scrambling the Nest Egg: How Well Do Teachers Understand Their Pensions, and What Do They Think about Alternative Pension Structures? Educ. Financ. Policy. 5 (4), 558-586.

DeCicca, P., Smith, J., 2013. The Long-Run Impacts of Early Childhood Education: Evidence from a Failed Policy Experiment. Econ. Educ. Rev. 36, 41-59.

Dell, M., 2010. The Persistent Effects of Peru's Mining Mita. Econometrica 78 (6), 18631903.

Deming, D.J, 2011. Better Schools, Less Crime? Q. J. Econ. 126 (4), 2063-2115.

Deming, D.J., Hastings, J.S, Kane, T.J., Staiger, D.O., 2013. School Choice, School Quality, and Postsecondary Attainment. Am. Econ. Rev. 104 (3), 991-1013.

Deming, D.J., 2014. Using School Choice Lotteries to Test Measures of School Effectiveness. NBER Working Paper No. 19803.

Dinkelman, T., Martinez, C.A., 2014. Investing in Schooling in Chile: The Role of Information about Financial Aid for Higher Education. Rev. Econ. Stat. 96 (2), 244-257. 
Dobbie, W., Fryer, R.G., 2011. Are High-Quality Schools Enough to Increase Achievement Among the Poor? Evidence from the Harlem Children's Zone. Am. Econ. J. - Appl. Econ. 3 (3), 158-187.

Dobbie, W., Fryer, R.G., 2013. Getting Beneath the Veil of Effective Schools: Evidence From New York City. Am. Econ. J. - Appl. Econ. 5 (4), 28-60.

Dobbie, W., Fryer, R.G., 2014. The Impact of Attending a School with High-Achieving Peers: Evidence from the New York City Exam Schools. Am. Econ. J. - Appl. Econ. 6 (3), 58-75.

Doyle, J.J., 2007. Child Protection and Child Outcomes: Measuring the Effects of Foster Care. Am. Econ. Rev. 97 (5), 1583-1610.

Dustmann, C., Machin, S., Schonberg, U., 2010. Ethnicity and Educational Achievement in Compulsory Schooling. Econ. J. 120 (546), F272-F297.

Dustmann, C., Schonberg, U., 2012. Expansions in Maternity Leave Coverage and Children's Long-Term Outcomes. Am. Econ. J. - Appl. Econ. 4 (3), 190-224.

Edin, P-A., Fredriksson, P., Aslund, O., 2003. Ethnic Enclaves and the Economic Success of Immigrants - Evidence from a Natural Experiment. Q. J. Econ. - 11(1), 329-57

Edwards, F., 2012. Early to Rise? The Effect of Daily Start Times on Academic Performance. Econ. Educ. Rev. 31 (6), 970-983.

Einav, L., Levin, J., 2013. The Data Revolution and Economic Analysis. NBER Working Paper No. 19035.

Engberg, J., Epple, D., Imbrogno, J., Sieg, H., Zimmer, R., 2014. Evaluating Education Programs That Have Lotteried Admission and Selective Attrition. J. Labor Econ. 32 (1), 27-63.

Engel, R.C., Gallagher, L.B., Lyle, D.S., 2010. Military Deployments and Children's Academic Achievement: Evidence from Department of Defense Education Activity Schools. Econ. Educ. Rev. 29 (1), 73-82.

Fairlie, R.W., Robinson, J., 2013. Experimental Evidence on the Effects of Home Computers on Academic Achievement among Schoolchildren. Am. Econ. J. - Appl. Econ. 5 (3), 211-240.

Falch, T., Strom, B., 2005. Teacher Turnover and Non-Pecuniary Factors. Econ. Educ. Rev. 24 (6), 611-631.

Falch, T., Naper, L.R., 2013. Educational Evaluation Schemes and Gender Gaps in Student Achievement. Econ. Educ. Rev. 36, 12-25. 
Feng, L., 2010. Hire Today, Gone Tomorrow: New Teacher Classroom Assignments and Teacher Mobility. Educ. Financ. Policy. 5 (3), 278-316.

Feng, L., Sass, T.R., 2013. What Makes Special-Education Teachers Special? Teacher Training and Achievement of Students with Disabilities. Econ. Educ. Rev. 36, 122-134.

Ferguson, J., Strauss, R.P., Vogt, W.B., 2006. The Effects of Defined Benefit Pension Incentives and Working Conditions on Teacher Retirement Decisions. Educ. Financ. Policy. 1 (3), 316-348.

Ferrie, J., Long, J., 2013. Intergenerational Occupational Mobility in Britain and the U.S. Since 1850. Am. Econ. Rev. 103(4), 1109-1137.

Figlio, D.N., Lucas, M.E., 2004. Do High Grading Standards Affect Student Performance? J. Public Econ. 89, 1815-1834.

Figlio, D.N., Lucas, M.E, 2004. What's in a Grade? School Report Cards and the Housing Market. Am. Econ. Rev. 94 (3), 591-604.

Figlio, D.N., Rouse, C.E., 2006. Do Accountability and Voucher Threats Improve LowPerforming Schools? J. Public Econ. 90, 239-255.

Figlio, D.N., 2006. Testing, Crime and Punishment. J. Public Econ. 90, 837-851.

Figlio, D.N., 2007. Boys Named Sue: Disruptive Children and Their Peers. Educ. Financ. Policy. 2 (4), 376-394.

Figlio, D.N., Hart, C.M.D., Metzger, M., 2010. Who Uses a Means-Tested Scholarship, and What Do They Choose? Econ. Educ. Rev. 29 (2), 301-317.

Figlio, D.N., Loeb, S., 2011. School Accountability. Handbook of Economics of Education 3, 383-421

Figlio, D.N., Hart, C.M.D., 2014. Competitive Effects of Means-Tested School Vouchers. Am. Econ. J. - Appl. Econ. 6 (1), 133-156.

Figlio, D.N., Guryan, J., Karbownik, K., Roth, J., 2014. The Effects of Poor Neonatal Health on Children's Cognitive Development. Am. Econ. Rev. 104(12), 3921-55.

Fitzpatrick, M.D., Lovenheim, M.F., 2014. Early Retirement Incentives and Student Achievement. Am. Econ. J. - Econ. Policy 6 (3), 120-154.

Fredriksson, P., Ockert, B., 2008. Resources and Student Achievement - Evidence from a Swedish Policy Reform. Scand. J. Econ. 110(2), 277-296.

Fredriksson, P., Ockert, B., Oosterbeek, H., 2013. Long-Term Effects of Class Size. Q. J. Econ. 128 (1), 249-285. 
Friesen, J., Hickey, R., Krauth, B., 2010. Disabled Peers and Academic Achievement. Educ. Financ. Policy. 5 (3), 317-348.

Fruehwirth, J.C., 2014. Can Achievement Peer Effect Estimates Inform Policy? A View from Inside the Black Box. Rev. Econ. Stat. 96 (3), 514-523.

Fryer, R.G, 2011. Financial Incentives and Student Achievement: Evidence from Randomized Trials. Q. J. Econ. 126 (4), 1755-1798.

Fryer, R.G., 2013. Teacher Incentives and Student Achievement: Evidence from New York City Public Schools. J. Labor Econ. 31 (2), 373-407.

Fryer, R.G., 2014. Injecting Charter School Best Practices into Traditional Public Schools: Evidence from Field Experiments. Q. J. Econ. 129(3), 1355-1407.

Fuller, S.C., Ladd, H.F., 2013. School-Based Accountability and the Distribution of Teacher Quality across Grades in Elementary School. Educ. Financ. Policy. 8 (4), 528559.

Gates, S.M., Ringel, J.S., Santibanez, L., Guarino, C., Ghosh-Dastidar, B., Brown, A., 2006. Mobility and Turnover Among School Principals. Econ. Educ. Rev. 25 (3), 289302.

Geay, C., McNally, S., Telhaj, S., 2013. Non-Native Speakers of English in the Classroom: What Are the Effects on Pupil Performance? Econ. J. 123 (570), F281-F307.

Gershenson, S., 2012. How Do Substitute Teachers Substitute? An Empirical Study of Substitute-Teacher Labor Supply. Econ. Educ. Rev. 31 (4), 410-430.

Gibbons, S., Silva, O., 2011. Faith Primary Schools: Better Schools or Better Pupils? J. Labor Econ. 29 (3), 589-635.

Gibbons, S., Silva, O., 2011. School Quality, Child Wellbeing and Parents' Satisfaction. Econ. Educ. Rev. 30 (2), 312-331.

Gibbons, S., Telhaj, S., 2011. Pupil Mobility and School Disruption. J. Public Econ. 95, 1156-1167.

Gibbons, S., Silva, O., Weinhardt, F., 2013. Everybody Needs Good Neighbours? Evidence from Students' Outcomes in England. Econ. J. 123 (571), 831-874.

Gimenez, L., Chou, S-Y., Liu, J-T., Liu. J-L., 2013. Parental Loss and Children's WellBeing. J. Hum. Resour. 48 (4), 1035-1071.

Glewwe, P., Kremer, M., Moulin, S., 2009. Many Children Left Behind? Textbooks and Test Scores in Kenya. Am. Econ. J. - Appl. Econ. 1 (1), 112-135. 
Goldhaber, D., 2007. Everyone's Doing It, But What Does Teacher Testing Tell us about Teacher Effectiveness? J. Hum. Resour. 42 (4), 765-794.

Goldhaber, D., Anthony, E., 2007. Can Teacher Quality Be Effectively Assessed? National Board Certification as a Signal of Effective Teaching. Rev. Econ. Stat. 89 (1), 134-150.

Goldhaber, D., Choi, H-J., Cramer, L., 2007. A Descriptive Analysis of the Distribution of NBPTS-Certified Teachers in North Carolina Econ. Educ. Rev. 26 (2), 160-172.

Goldhaber, D., Hansen, M., 2009. National Board Certification and Teachers' Career Paths: Does Nbpts Certification Influence How Long Teachers Remain in The Profession and Where They Teach? Educ. Financ. Policy. 4 (3), 229-262.

Goldhaber, D., Walch, J., 2012. Strategic Pay Reform: A Student Outcomes-Based Evaluation of Denver's Procomp Teacher Pay Initiative. Econ. Educ. Rev. 31 (6), 10671083.

Goldhaber, D., Cowan, J., Walch, J., 2013. Is a Good Elementary Teacher Always Good? Assessing Teacher Performance Estimates across Subjects. Econ. Educ. Rev. 36, 216228.

Goldhaber, D., Liddle, S., Theobald, R., 2013. The Gateway to the Profession: Assessing Teacher Preparation Programs Based on Student Achievement. Econ. Educ. Rev. 34, 2944.

Goldhaber, D., Theobald, R., 2013. Managing the Teacher Workforce in Austere Times: The Determinants and Implications of Teacher Layoffs. Educ. Financ. Policy. 8 (4), 494527.

Golsteyn, B., Gronqvist, H., Lindahl, L., 2014. Adolescent Time Preferences Predict Lifetime Outcomes. Econ. J. 124(580), F739-F761.

Goodman, J., 2008. Who Merits Financial Aid?: Massachusetts' Adams Scholarship. J. Public Econ. 92, 2121-2131.

Goodman, J., 2010. Skills, Schools, and Credit Constraints: Evidence from Massachusetts. Educ. Financ. Policy. 5 (1), 36-53.

Goodman, J., 2014. Flaking Out: Student Absences and Snow Days as Disruptions of Instructional Time. NBER Working Paper No. 20221.

Gould, E.D., Lavy, V., Paserman, D.M., 2004. Immigrating to Opportunity: Estimating the Effect of School Quality Using a Natural Experiment on Ethiopians in Israel. Q. J. Econ. 119 (2), 489-526. 
Gould, E.D., Lavy, V., Paserman, M.D., 2009. Does Immigration Affect the Long-Term Educational Outcomes of Natives? Quasi-Experimental Evidence. Econ. J. 119 (540), 1243-1269.

Greene, J.P., Winters, M.A., 2007. Revisiting Grade Retention: An Evaluation of Florida's Test-Based Promotion Policy. Educ. Financ. Policy. 2 (4), 319-340.

Greene, J.P., Winters, M.A., 2009. The Effects of Exemptions to Florida's Test-Based Promotion Policy: Who Is Retained? Who Benefits Academically? Econ. Educ. Rev. 28 (1), 135-142.

Gritz, M.R., Theobald, N.D., 1996. The Effects of School District Spending Priorities on Length of Stay in Teaching. J. Hum. Resour. 31 (3), 477-512.

Gronqvist, H., Hall, C., 2013. Education Policy and Early Fertility: Lessons from an Expansion of Upper Secondary Schooling. Econ. Educ. Rev. 37, 13-33.

Guardiano, C.M., Brown, A.B., Wyse, A.E., 2011. Can Districts Keep Good Teachers in the Schools That Need Them Most? Econ. Educ. Rev. 30 (5), 962-979.

Gupta, N.D., Simonsen, M., 2010. Non-Cognitive Child Outcomes and Universal High Quality Child Care. J. Public Econ. 94, 30-43.

Haegeland, T., Raaum, O., Salvanes, K.G., 2012. Pennies from Heaven? Using Exogenous Tax Variation to Identify Effects of School Resources on Pupil Achievement. Econ. Educ. Rev. 31 (5), 601-614.

Hakkinen, I., Kirjavainen, T., Uusitalo, R., 2003. School Resources and Student Achievement Revisited: New Evidence from Panel Data. Econ. Educ. Rev. 22 (3), 329335 .

Hall, C., 2012. The Effects of Reducing Tracking in Upper Secondary School: Evidence from a Large-Scale Pilot Scheme. J. Hum. Resour. 47 (1), 237-269.

Hanushek, E.A., 1992. The Trade-off between Child Quantity and Quality. J. Polit. Econ. 100 (1), 84-117.

Hanushek, E.A., Kain, J.F., Rivkin, S.G., 2002. Inferring Program Effects for Special Populations: Does Special Education Raise Achievement for Students With Disabilities? Rev. Econ. Stat. 84 (4), 584-599.

Hanushek, E.A., Kain, J.F., Rivkin, S.G., 2004. Why Public Schools Lose Teachers. J. Hum. Resour. 39 (2), 326-354.

Hanushek, E.A., Kain, J.F., Rivkin, S.G., 2004. Disruption Versus Tiebout Improvement: The Costs and Benefits of Switching Schools. J. Public Econ. 88, 1721-1746. 
Hanushek, E.A., Kain, J.F., Rivkin, S.G., Branch, G.F., 2007. Charter School Quality and Parental Decision Making with School Choice. J. Public Econ. 91, 823-848.

Hanushek, E.A., Kain, J.F., Rivkin, S.G., 2009. New Evidence about Brown v. Board of Education : The Complex Effects of School Racial Composition on Achievement. J. Labor Econ. 27 (3), 349-383.

Harris, D.N., Sass, T.R., 2011. Teacher Training, Teacher Quality and Student Achievement. J. Public Econ. 95, 798-812.

Harris, D.N., Sass, T.R., 2014. Skills, Productivity and the Evaluation of Teacher Performance. Econ. Educ. Rev. 40, 183-204.

Hastings, J.S., Kane, T.J., Staiger, D.O., Weinstein, J.M., 2007. The Effect of Randomized School Admissions on Voter Participation. J. Public Econ. 91, 915-937.

Hastings, J.S., Weinstein, J.M., 2008. Information, School Choice, and Academic Achievement: Evidence from Two Experiments. Q. J. Econ. 123 (4), 1373-1414.

Havnes, T., Mogstad, M., 2011. No Child Left Behind: Subsidized Child Care and Children's Long-Run Outcomes. Am. Econ. J. - Econ. Policy 3 (2), 97-129.

Havens, T., Mogstad, M., 2014. Is Universal Child Care Leveling the Playing Field. J. Public Econ. 127, 100-114.

Heers, M., Van Klaveren, C., Groot, W., Van den Brink, H.M., 2014. The Impact of Community Schools on Student Dropout in Pre-Vocational Education. Econ. Educ. Rev. 41, 105-119.

Heinesen, E., 2010. Estimating Class-Size Effects using Within-School Variation in Subject-Specific Classes. Econ. J. 120 (545), 737-760.

Hendricks, M.D., 2014. Does it Pay to Pay Teachers More? Evidence from Texas. J. Public Econ. 109, 50-63.

Henry, G.T., Bastian, K.C., Fortner, C.K., Kershaw, D.C., Purtell, K.M., Thompson, C.L., Zulli, R.A., 2014. Teacher Preparation Policies and their Effects on Student Achievement. Educ. Financ. Policy. 9 (3), 264-303.

Hensvik, L., 2012. Competition, Wages and Teacher Sorting: Lessons Learned from a Voucher Reform. Econ. J. 122 (561), 799-824.

Hermann, M.A., Rockoff, J.E., 2012. Worker Absence and Productivity: Evidence from Teaching. J. Labor Econ. 30 (4), 749-782.

Hilbert, M., Lopez, P., 2011. The World's Technological Capacity to Store, Communicate, and Compute Information. Science 332, 60-65. 
Hinnerich, B.T., Hoglin, E., Johannesson, M., 2011. Are Boys Discriminated in Swedish High Schools? Econ. Educ. Rev. 30 (4), 682-690.

Hinrichs, P., 2011. When the Bell Tolls: The Effects of School Starting Times on Academic Achievement. Educ. Financ. Policy. 6 (4), 486-507.

Holmlund, H., McNally, S., Viarengo, M., 2010. Does Money Matter for Schools? Econ. Educ. Rev. 29 (6), 1154-1164.

Holmlund, H., Lindahl, M., Plug, E., 2011. The Causal Effect of Parents' Schooling on Children's Schooling: A Comparison of Estimation Methods. J.Econ. Lit. 49 (3), 615651.

Imazeki, J., 2005. Teacher Salaries and Teacher Attrition. Econ. Educ. Rev. 24 (4), 431 449.

Imberman, S.A., 2011. Achievement and Behavior in Charter Schools: Drawing a More Complete Picture. Rev. Econ. Stat. 93 (2), 416-435.

Imberman, S.A., 2011. The Effect of Charter Schools on Achievement and Behavior of Public School Students. J. Public Econ. 95, 850-863.

Imberman, S.A., Kugler A.D., Sacerdote B.I., 2012. Katrina's Children: Evidence on the Structure of Peer Effects from Hurricane Evacuees. Am. Econ. Rev. 102 (5), 2048-2082.

Imberman, S.A., Lovenheim, M., 2015. Incentive Strength and Teacher Productivity: Evidence from a Group-Based Teacher Incentive Pay System. Rev. Econ. Stat. 97(2), 364-386.

Jackson, C.K., 2009. Student Demographics, Teacher Sorting, and Teacher Quality: Evidence from the End of School Desegregation. J. Labor Econ. 27 (2), 213-256.

Jackson, C.K., Bruegmann, E., 2009. Teaching Students and Teaching Each Other: The Importance of Peer Learning for Teachers. Am. Econ. J. - Appl. Econ. 1 (4), 85-108.

Jackson, C.K., 2010. Do Students Benefit from Attending Better Schools? Evidence from Rule-Based Student Assignments in Trinidad and Tobago. Econ. J. 120 (549), 13991429.

Jackson, C.K., 2012. Single-Sex Schools, Student Achievement, and Course Selection: Evidence from Rule-Based Student Assignments in Trinidad and Tobago. J. Public Econ. 96, 173-187.

Jackson, C.K., 2012. School Competition and Teacher Labor Markets: Evidence from Charter School Entry in North Carolina. J. Public Econ. 96, 431-448.

Jackson, C.K., 2013. Can Higher-Achieving Peers Explain the Benefits to Attending Selective Schools? Evidence from Trinidad and Tobago. J. Public Econ. 108, 63-77. 
Jackson, K.C., 2013. Match Quality, Worker Productivity, and Worker Mobility: Direct Evidence from Teachers. Rev. Econ. Stat. 95 (4), 1096-1116.

Jackson, C.K., 2014. Teacher Quality at the High-School Level: The Importance of Accounting for Tracks. J. Labor Econ. 32(4), 645-684.

Jacob, B.A., Levitt, S., 2003. Rotten Apples: an Investigation of the Prevalence and Predictors of Teacher Cheating. Q. J. Econ. 118 (3), 843-877.

Jacob, B.A, 2004. Public Housing, Housing Vouchers, and Student Achievement: Evidence from Public Housing Demolitions in Chicago. Am. Econ. Rev. 94 (1), 233-258.

Jacob, B.A., Lefgren, L., 2004. The Impact of Teacher Training on Student Achievement: Quasi-Experimental Evidence from School Reform Efforts in Chicago. J. Hum. Resour. 39 (1), 50-79.

Jacob, B.A., Lefgren, L., 2004. Remedial Education and Student Achievement: A Regression-Discontinuity Analysis. Rev. Econ. Stat. 86 (1), 226-244.

Jacob, B.A., 2005. Accountability, Incentives and Behavior: the Impact of High-Stakes Testing in the Chicago Public Schools. J. Public Econ. 89, 761-796.

Jacob, B.A., Lefgren, L., 2007. What do Parents Value in Education? An Empirical Investigation of Parents' Revealed Preferences for Teachers. Q. J. Econ. 122 (4), 16031637.

Jacob, B.A., Lefgren, L., 2008. Can Principals Identify Effective Teachers? Evidence on Subjective Performance Evaluation in Education. J. Labor Econ. 26 (1), 101-136.

Jacob, B.A., Lefgren, L., 2009. The Effect of Grade Retention on High School Completion. Am. Econ. J. - Appl. Econ. 1 (3), 33-58.

Jacob, B.A., Lefgren, L., Sims, D.P., 2010. The Persistence of Teacher-Induced Learning. J. Hum. Resour. 45 (4), 915-943.

Jacob, B.A., Walsh, E., 2011. What's in a Rating? Econ. Educ. Rev. 30 (3), 434-448.

Jacob, B.A., 2013. The Effect of Employment Protection on Teacher Effort. J. Labor Econ. 31 (4), 727-761.

Jacob, B., Kapustin, M., Ludwig, J., 2014. Human Capital Effects of Anti-Poverty Programs: Evidence from a Randomized Housing Voucher Lottery. NBER Working Paper No. 20164.

Jalava, N., Joensen, J., Pellas, E.M., 2015. Grades and Rank: Impacts of Non-Financial Incentives on Test Performance. J. Econ. Behav. Organ. 115, 161-196. 
Jensen, P., Rasmussen, A.W., 2011. The Effect of Immigrant Concentration in Schools on Native and Immigrant Children's Reading and Math Skills. Econ. Educ. Rev. 30 (6), 1503-1515.

Jepsen, C., 2010. Bilingual Education and English Proficiency. Educ. Financ. Policy. 5 (2), 200-227.

Joensen, J.S., Nielsen, H.S., 2009. Is there a Causal Effect of High School Math on Labor Market Outcomes? J. Hum. Resour. 44 (1), 171-198.

Kane, T.J., Rockoff, J.E., Staiger, D.O., 2008. What Does Certification Tell Us About Teacher Effectiveness? Evidence from New York City. Econ. Educ. Rev. 27 (6), 615631.

Kane, T., Taylor, E.S., Tyler, J.H., Wooten, A.L. 2011. Identifying Effective Classroom Practices Using Student Achievement Data. J. Hum. Resour. 46 (3), 587-613.

Karbownik, K., 2014. Do Changes in Student Quality Affect Teacher Mobility? Evidence from an Admission Reform. IFAU Working Paper 2014:15.

Kasman, M., Loeb, S., 2013. Principals' Perceptions of Competition for Students in Milwaukee Schools. Educ. Financ. Policy. 8 (1), 43-73.

Kerr, S.P., Pekkarinen, T., Uusitalo, R., 2013. School Tracking and Development of Cognitive Skills. J. Labor Econ. 31 (3), 577-602.

Keslair, F., Maurin, E., McNally, S., 2012. Every Child Matters? An Evaluation of "Special Educational Needs" Programmes in England. Econ. Educ. Rev. 31 (6), 932-948.

Kinsler, J., 2011. Understanding the Black-White School Discipline Gap. Econ. Educ. Rev. 30 (6), 1370-1383.

Kinsler, J., 2012. Beyond Levels and Growth: Estimating Teacher Value-Added and its Persistence. J. Hum. Resour. 47 (3), 722-753.

Klopfenstein, K., 2004. Advanced Placement: Do Minorities Have Equal Opportunity? Econ. Educ. Rev. 23 (2), 115-131.

Koedel, C., 2009. An Empirical Analysis of Teacher Spillover Effects in Secondary School. Econ. Educ. Rev. 28 (6), 682-692.

Koedel, C., Betts, J., 2010. Value Added to What? How a Ceiling in the Testing Instrument Influences Value-Added Estimation. Educ. Financ. Policy. 5 (1), 54-81.

Koedel, C., Betts, J.R., 2011. Does Student Sorting Invalidate Value-Added Models of Teacher Effectiveness? An Extended Analysis of the Rothstein Critique. Educ. Financ. Policy. 6 (1), 18-42. 
Koedel, C., Ni, S., Podgursky, M., 2014. Who Benefits From Pension Enhancements? Educ. Financ. Policy. 9 (2), 165-192.

Kremer, M., Miguel, E., Thornton, R., 2009. Incentives to Learn. Rev. Econ. Stat. 91 (3), 437-456.

Krieg, J.M., 2006. Teacher Quality and Attrition. Econ. Educ. Rev. 25 (1), 13-27.

Krieg, J.M., 2008. Are Students Left Behind? The Distributional Effects of the No Child Left Behind Act. Educ. Financ. Policy. 3 (2), 250-281.

Krieg, J.M, 2011. Which Students Are Left Behind? The Racial Impacts of the No Child Left Behind Act. Econ. Educ. Rev. 30 (4), 654-664.

Kukla-Acevedo, S., 2009. Do Teacher Characteristics Matter? New Results on the Effects of Teacher Preparation on Student Achievement. Econ. Educ. Rev. 28 (1), 49-57.

Ladd, H.F., Walsh, R.P., 2002. Implementing Value-Added Measures of School Effectiveness: Getting the Incentives Right. Econ. Educ. Rev. 21 (1), 1-17.

Ladd, H.F., Muschkin, C., Dodge, K., 2012. From Birth to School: Early Childhood Initiatives and Third Grade Outcomes in North Carolina. Mimeo.

Lai, F., Sadoulet, E., De Janvry, A., 2009. The Adverse Effects of Parents' School Selection Errors on Academic Achievement: Evidence from the Beijing Open Enrollment Program. Econ. Educ. Rev. 28 (4), 485-496.

Lai, F., 2010. Are Boys Left Behind? The Evolution of the Gender Achievement Gap in Beijing's Middle Schools. Econ. Educ. Rev. 29 (3), 383-399.

Lai, F., Sadoulet, E., de Janvry, A., 2011. The Contributions of School Quality and Teacher Qualifications to Student Performance Evidence from a Natural Experiment in Beijing Middle Schools. J. Hum. Resour. 46 (1), 123-153.

Lankford, H., Wyckoff, J., 1997. The Changing Structure of Teacher Compensation, 1970-94. Econ. Educ. Rev. 16 (4), 371-384.

Lavy, V., Schlosser, A., 2005. Targeted Remedial Education for Underperforming Teenagers: Costs and Benefits. J. Labor Econ. 23 (4), 839-874.

Lavy, V., 2008. Do Gender Stereotypes Reduce Girls' or Boys' Human Capital Outcomes? Evidence from a Natural Experiment. J. Public Econ. 92, 2083-2105.

Lavy, V., 2009. Performance Pay and Teachers' Effort, Productivity, and Grading Ethics. Am. Econ. Rev. 99 (5), 1979-2011.

Lavy, V., 2010. Effects of Free Choice among Public Schools. Rev. Econ. Stud. 77 (3), 1164-1191. 
Lavy, V., Schlosser, A., 2011. Mechanisms and Impacts of Gender Peer Effects at School. Am. Econ. J. - Appl. Econ. 3 (2), 1-33.

Lavy, V., Paserman, M.D., 2012. Inside The Black Box of Ability Peer Effects: Evidence from Variation in the Proportion of Low Achievers in the Classroom. Econ. J. 122 (559), 208-237.

Lavy, V., Silva, O., Weinhardt, F., 2012. The Good, the Bad, and the Average: Evidence on Ability Peer Effects in Schools. J. Labor Econ. 30 (2), 367-414.

Lavy, V., 2013. Gender Differences in Market Competitiveness in a Real Workplace: Evidence from Performance-Based Pay Tournaments among Teachers. Econ. J. 123 (569), 540-573.

Lavy, V., 2014. Long Run Effects of Free School Choice: College Attainment, Employment, Earnings, and Social Outcomes at Adulthood. Mimeo

Leach, J., Payne, A.A., Chan, S., 2010. The Effects of School Board Consolidation and Financing on Student Performance. Econ. Educ. Rev. 29 (6), 1034-1046.

Leigh, A., 2010. Estimating Teacher Effectiveness from Two-Year Changes in Students' Test Scores. Econ. Educ. Rev. 29 (3), 480-488.

Leos-Urbel, J., Schwartz, A.E., Weinstein, M., Corcoran, S., 2013. Not Just for Poor Kids: The Impact of Universal Free School Breakfast on Meal Participation and Student Outcomes. Econ. Educ. Rev. 36, 88-107.

Leuven, E, Lindahl, M., Oosterbeek, H., Webbink, D., 2007. The Effect of Extra Funding for Disadvantaged Pupils on Achievement. Rev. Econ. Stat. 89 (4), 721-736.

Lockwood, J.R., McCaffrey, D.F., 2009. Exploring Student-Teacher Interactions in Longitudinal Achievement Data. Educ. Financ. Policy. 4 (4), 439-467.

Loeb, S., Kalogrides, D., Beteille, T., 2012. Effective Schools: Teacher Hiring, Assignment, Development, and Retention. Educ. Financ. Policy. 7 (3), 269-304.

Loken, K.V., Mogstad, M., Wiswall, M., 2012. What Linear Estimators Miss: The Effects of Family Income on Child Outcomes. Am. Econ. J. - Appl. Econ. 4 (2), 1-35.

Lucas, A.M., Mbiti, I.M., 2012. Access, Sorting, and Achievement: The Short-Run Effects of Free Primary Education in Kenya. Am. Econ. J. - Appl. Econ. 4 (4), 226-253.

Lucas, A.M., Mbiti, I.M., 2014. Effects of School Quality on Student Achievement: Discontinuity Evidence from Kenya. Am. Econ. J. - Appl. Econ. 6 (3), 234-263.

Lundborg, P., Nilsson, A., Rooth, D-O., 2014. Parental Education and Offspring Outcomes: Evidence from the Swedish Compulsory School Reform. Am. Econ. J. - Appl. Econ. 6 (1), 253-278. 
Lyle, D.S., 2006. Using Military Deployments and Job Assignments to Estimate the Effect of Parental. J. Labor Econ. 24 (2), 319-350.

Macartney, H., 2014. The Dynamic Effects of Educational Accountability. NBER Working Paper No. 19915.

Machin, S., McNally, S., Silva, O., 2007. New Technology in Schools: Is There a Payoff? Econ. J. 117 (522), 1145-1167.

Manacorda, M., 2012. The Cost of Grade Retention. Rev. Econ. Stat. 94 (2), 596-606.

Mansfield, R.K., 2014. Teacher Quality and Student Inequality. J. Labor Econ. 33(3), 751-788.

Matsudaira, J.D., Hosek, A., Walsh, E., 2012. An Integrated Assessment of the Effects of Title I on School Behavior, Resources, and Student Achievement. Econ. Educ. Rev. 31 (3), 1-14.

McCaffrey, D.F., Sass, T.R., Lockwood, J.R., Mihaly, K., 2009. The Intertemporal Variability of Teacher Effect Estimates. Educ. Financ. Policy. 4 (4), 572-606.

McEwan, P.J., 2003. Peer Effects on Student Achievement: Evidence from Chile. Econ. Educ. Rev. 22 (2), 131-141.

McEvan, P.J., Shapiro, J.S., 2008. The Benefits of Delayed Primary School Enrollment: Discontinuity Estimates Using Exact Birth Dates. J. Hum. Resour. 43 (1), 1-29.

McEwan, P.J, 2013. The Impact of Chile's School Feeding Program on Education Outcomes. Econ. Educ. Rev. 32, 122-139.

McMullen, S.C., Rouse, K.E., 2012. The Impact of Year-Round Schooling on Academic Achievement: Evidence from Mandatory School Calendar Conversions. Am. Econ. J. Econ. Policy 4 (4), 230-252.

McMullen, S.C, Rouse, K.E., 2012. School Crowding, Year-Round Schooling, and Mobile Classroom Use: Evidence from North Carolina. Econ. Educ. Rev. 31 (5), 812823.

Meghir, C., Palme, M., 2005. Educational Reform, Ability, and Family Background. Am. Econ. Rev. 95 (1), 414-424.

Meghir, C., Palme, M., Schnabel, M., 2012.The Effect of Education Policy on Crime: An Intergenerational Perspective. NBER Working Paper No. 18145.

Meyer, E., Van Klaveren, C., 2013. The Effectiveness of Extended Day Programs: Evidence from a Randomized Field Experiment in the Netherlands. Econ. Educ. Rev. 36, $1-11$. 
Mihaly, K., McCaffrey, D., Sass, T.R., Lockwood, J.R., 2013. Where You Come from or Where You Go? Distinguishing Between School Quality and the Effectiveness of Teacher Preparation Program Graduates. Educ. Financ. Policy. 8 (4), 459-493.

Miller, L.C, Mittleman, J., 2012. High Schools That Work and College Preparedness: Measuring the Model's Impact on Mathematics and Science Pipeline Progression. Econ. Educ. Rev. 31 (6), 1116-1135.

Miller, A., 2013. Principal Turnover and Student Achievement. Econ. Educ. Rev. 36, 6072 .

Mizal, A., Roumaguera, P., 2000. School Performance and Choice: The Chilean Experience. J. Hum. Resour. 35 (2), 392-417.

Muhlenweg, A.M., Puhani, P.A., 2010. The Evolution of the School-Entry Age Effect in a School Tracking System. J. Hum. Resour. 45 (2), 407-438.

Murnane, R.J., Olsen, R.J., 1990. The Effects of Salaries and Opportunity Costs on Length of Stay in Teaching: Evidence from North Carolina. J. Hum. Resour. 25 (1), 106124.

Naper, L.N., 2010. Teacher Hiring Practices and Educational Efficiency. Econ. Educ. Rev. 29 (4), 658-668.

Neal, D., Schanzenbach, D.W., 2010. Left Behind by Design: Proficiency Counts and Test-Based Accountability. Rev. Econ. Stat. 92 (2), 263-283.

Ni, Y., Rorrer, A.K., 2012. Twice Considered: Charter Schools and Student Achievement in Utah. Econ. Educ. Rev. 31 (5), 835-849.

Oreopoulos, P., Stabile, M., Walld, R., Roos, L.L., 2008. Short-, Medium-, and LongTerm Consequences of Poor Infant Health: An Analysis Using Siblings and Twins. J. Hum. Resour. 43 (1), 88-138.

Ortega, D.E., 2010. The Effect of Wage Compression and Alternative Labor Market Opportunities on Teacher Quality in Venezuela. Econ. Educ. Rev. 29 (5), 760-771.

Ost, B., 2014. How Do Teachers Improve? The Relative Importance of Specific and General Human Capital. Am. Econ. J. - Appl. Econ. 6 (2), 127-151.

Ou, D., 2010. To Leave or not to Leave? A Regression Discontinuity Analysis of the Impact of Failing the High School Exit Exam. Econ. Educ. Rev. 29 (2), 171-186.

Ouazad, A., Page, L., 2013. Students' Perceptions of Teacher Biases: Experimental Economics in Schools. J. Public Econ. 105, 116-130. 
Palme, M., Lindahl, M., Massih, S.S., Sjogren, A., 2014. Long-term Intergenerational Persistence of Human Capital: An Empirical Analysis of Four Generations. J. Hum. Resour. 50(1), 1-33.

Paredes, V., 2014. A Teacher Like Me or a Student Like Me? Role Model Versus Teacher Bias Effect. Econ. Educ. Rev. 39, 38-49.

Pathak, P.A., Shi, P., 2014. Demand Modeling, Forecasting, and Counterfactuals, Part I. NBER Working Paper No. 19859.

Player, D., 2010. Nonmonetary Compensation in the Public Teacher Labor Market. Educ. Financ. Policy. 5 (1), 82-103.

Podgursky, M., Monroe, R., Watson, D., 2004. The Academic Quality of Public School Teachers: An Analysis of Entry and Exit Behavior. Econ. Educ. Rev. 23 (5), 507-518.

Pop-Eleches, C., Urquiola, M., 2013. Going to a Better School: Effects and Behavioral Responses. Am. Econ. Rev. 103 (4), 1289-1324.

Ransom, M.R., Sims, D.P., 2010. Estimating the Firm's Labor Supply Curve in a "New Monopsony" Framework: Schoolteachers in Missouri. J. Labor Econ. 28 (2), 331-355.

Ray, A., McCormack, T., Evans, H., 2009. Value Added in English Schools. Educ. Financ. Policy. 4 (4), 415-438.

Reback, R., 2008. Teaching to the Rating: School Accountability and the Distribution of Student Achievement. J. Public Econ. 92, 1394-1415.

Rege, M., Telle, K., Votruba, M., 2011. Parental Job Loss and Children's School Performance. Rev. Econ. Stud. 78 (4), 1462-1489.

Reinikka, R., Svensson, J., 2011. The Power of Information in Public Services: Evidence from Education in Uganda. J. Public Econ. 95, 956-966.

Rivkin, S.G., Hanushek, E.A., Kain, J.F., 2005. Teachers, Schools, and Academic Achievement. Econometrica 73 (2), 417-458.

Robsertson, E., 2011. The Effects of Quarter of Birth on Academic Outcomes at the Elementary School Level. Econ. Educ. Rev. 30 (2), 300-311.

Rockoff, J.E., Staiger, D.O., Kane, T.J., Taylor, E.S., 2012. Information and Employee Evaluation: Evidence from a Randomized Intervention in Public Schools. Am. Econ. Rev. 102 (7), 3184-3213.

Rockoff, J.E., Lockwood, B.B., 2010. Stuck in the Middle: Impacts of Grade Configuration in Public Schools. J. Public Econ. 94, 1051-1061. 
Rockoff, J.E., Jacob, B.A., Kane, T.J., Staiger, D.O., 2011. Can You Recognize an Effective Teacher When You Recruit One? Educ. Financ. Policy. 6 (1), 43-74.

Roed, K., Raaum, O., 2003. Administrative Registers: Unexplored Reservoirs of Scientific Knowledge? Econ. J. 113 (488), F258-F281.

Rothstein, J., 2010. Teacher Quality in Educational Production: Tracking, Decay, and Student Achievement. Q. J. Econ. 125 (1), 175-214.

Rothstein, J., 2009. Student Sorting and Bias in Value-Added Estimation: Selection on Observables and Unobservables. Educ. Financ. Policy. 4 (4), 537-571.

Rouse, C.E., Hannaway, J., Goldhaber, D., Figlio, D., 2013. Feeling the Florida Heat? How Low-Performing Schools Respond to Voucher and Accountability Pressure. Am. Econ. J.: Econ. Policy 5(2), 251-281.

Rubenstein, R., Schwartz, A.E., Stiefel, L., Zabel, J., 2009. Spending, Size, and Grade Span in K-8 Schools. Educ. Financ. Policy. 4 (1), 60-88.

Sacerdote, B., 2012. When the Saints Go Marching Out: Long-Term Outcomes for Student Evacuees from Hurricanes Katrina and Rita. Am. Econ. J. - Appl. Econ. 4 (1), 109-135.

Sanders, N.J, 2012. What Doesn't Kill You Makes You Weaker. Prenatal Pollution Exposure and educational Outcomes. J. Hum. Resour. 47 (3), 826-850.

Sandstrom, M.F., Bergstrom, F., 2005. School Vouchers in Practice: Competition Will Not Hurt You. J. Public Econ. 89, 351-380.

Sass, T.R., 2006. Charter Schools and Student Achievement in Florida. Educ. Financ. Policy. 1 (1), 91-122.

Sass, T.R., Semykina, A., Harris, D.N., 2014. Value-Added Models and the Measurement of Teacher Productivity. Econ. Educ. Rev. 38, 9-23.

Scafidi, B., Sjoquist, D.L., Stinebrickner, T.R., 2007. Race, Poverty, and Teacher Mobility. Econ. Educ. Rev. 26 (2), 145-159.

Schneeweis, N., Zweimuller, M., 2012. Girls, Girls, Girls: Gender Composition and Female School Choice. Econ. Educ. Rev. 31 (4), 482-500.

Schwartz, A.E., Stiefel, L., Kim, D.Y., 2004. The Impact of School Reform on Student Performance: Evidence From the New York Network for School Renewal Project. J. Hum. Resour. 39 (2), 500-522.

Schwartz, A.E., Stiefel, L., 2006. Is There a Nativity Gap? New Evidence on the Academic Performance of Immigrant Students. Educ. Financ. Policy. 1 (1), 17-49. 
Schwerdt, G., West, M.R., 2013. The Impact of Alternative Grade Configurations on Student Outcomes through Middle and High School. J. Public Econ. 97, 308-326.

Smith, J., 2010. How Valuable Is the Gift of Time? The Factors That Drive the Birth Date Effect in Education. Educ. Financ. Policy. 5 (3), 247-277.

Soderstrom, M., Uusitalo, R., 2010. School Choice and Segregation: Evidence from an Admission Reform. Scand. J. Econ. 112(1), 55-76.

Springer, M.G., 2008. The Influence of an NCLB Accountability Plan on the Distribution of Student Test Score Gains. Econ. Educ. Rev. 27 (5), 556-563.

Steinberg, M.P., 2014. Does Greater Autonomy Improve School Performance? Evidence from a Regression Discontinuity Analysis in Chicago. Educ. Financ. Policy. 9 (1), 1-35.

Strain, M.R., 2013. Single-Sex Classes \& Student Outcomes: Evidence from North Carolina. Econ. Educ. Rev. 36, 73-87.

Streams, M., Butler, J.S., Cowen, J., Fowles, J., Toma, E.F., 2011. School Finance Reform: Do Equalized Expenditures Imply Equalized Teacher Salaries? Educ. Financ. Policy. 6 (4), 508-536.

Sund, K., 2009. Estimating Peer Effects in Swedish High School Using School, Teacher, and Student Fixed Effects. Econ. Educ. Rev. 28 (3), 329-336.

Taylor, E.S., Tyler, J.H., 2012. The Effect of Evaluation on Teacher Performance. Am. Econ. Rev. 102 (7), 3628-3651.

Taylor, E., 2014. Spending More of the School Day in Math Class: Evidence from a Regression Discontinuity in Middle School. J. Public Econ. 117, 162-181.

Theobald, N.D., 1990. An Examination of the Influence of Personal, Professional, and School District Characteristics on Public School Teacher Retention. Econ. Educ. Rev. 9 (3), 241-250.

Theobald, N.D., Gritz, M.R., 1996. The Effects of School District Spending Priorities on the Exit Paths of Beginning Teachers Leaving the District. Econ. Educ. Rev. 15 (1), 11 22.

Thieme, C., Prior, D., Tortosa-Ausina, E., 2013. A Multilevel Decomposition of School Performance Using Robust Nonparametric Frontier Techniques. Econ. Educ. Rev. 32, 104-121.

Tuck, B., Berman, M., Hill, A., 2009. Local Amenities, Unobserved Quality, and Market Clearing: Adjusting Teacher Compensation to Provide Equal Education Opportunities. Econ. Educ. Rev. 28 (1), 58-66. 
Tyler, J.H, Murnane, R.J., Willett, J.B., 2000. Estimating the Labor Market Signaling Value of the GED. Q. J. Econ. 115 (2), 431-468.

Tyler, J.H., Murnane, R.J., Willett, J.B., 2004. The Devil's in the Details: Evidence from the GED on Large Effects of Small Differences in High Stakes Exams. Econ. Educ. Rev. 23 (4), 339-349.

Tyler, J.H., Lofstrom, M., 2010. Is the GED an Effective Route to Postsecondary Education for School Dropouts? Econ. Educ. Rev. 29 (5), 813-825.

Urquiola, M., Verhoogen, E., 2009. Class-Size Caps, Sorting, and the RegressionDiscontinuity Design. Am. Econ. Rev. 99 (1), 179-215.

Waldo, S., 2007. On the Use of Student Data in Efficiency Analysis-Technical Efficiency in Swedish Upper Secondary School. Econ. Educ. Rev. 26 (2), 173-185.

Weiss, M.J., May, H., 2012. A Policy Analysis of the Federal Growth Model Pilot Program's Measures of School Performance: The Florida Case. Educ. Financ. Policy. 7 (1), 44-73.

West, M.R., Peterson, P.E., 2006. The Efficacy of Choice Threats within School Accountability Systems: Results from Legislatively Induced Experiments. Econ. J. 116 (510), C46-C62.

Wikstrom, C., Wikstrom, M., 2005. Grade Inflation and School Competition: An Empirical Analysis Based on the Swedish Upper Secondary Schools. Econ. Educ. Rev. 24 (3), 309-322.

Winters, M.A., Trivitt, J.R., Greene, J.P., 2010. The Impact of High-Stakes Testing on Student Proficiency in Low-Stakes Subjects: Evidence from Florida's Elementary Science Exam. Econ. Educ. Rev. 29 (1), 138-146.

Winters, M.A., 2012. Measuring the Effect of Charter Schools on Public School Student Achievement in an Urban Environment: Evidence from New York City. Econ. Educ. Rev. 31 (2), 293-301.

Winters. M.A., Dixon, B.L., Greene, J.P., 2012. Observed Characteristics and Teacher Quality: Impacts of Sample Selection on a Value Added Model. Econ. Educ. Rev. 31 (1), 19-32.

Winters, M.A, Greene, J.P., 2012. The Medium-Run Effects of Florida's Test-Based Promotion Policy. Educ. Financ. Policy. 7 (3), 305-330.

Winters, M.A., Haight, R.C., Swaim, T.T., Pickering, K.A., 2013. The Effect of SameGender Teacher Assignment on Student Achievement in the Elementary and Secondary Grades: Evidence from Panel Data. Econ. Educ. Rev. 34, 69-75.

Wiswall, M., 2013. The Dynamics of Teacher Quality. J. Public Econ. 100, 61-78. 
Wiswall, M., Stiefel, L., Schwartz, A.E., Boccardo, J., 2014. Does Attending a STEM High School Improve Student Performance? Evidence from New York City. Econ. Educ. Rev. 40, 93-105.

Zabel, J.E., 2008. The Impact of Peer Effects on Student Outcomes in New York City Public Schools. Educ. Financ. Policy. 3 (2), 197-249.

Zimmer, R., Gill, B., Booker, K., Lavertu, S., Witte, J., 2012. Examining Charter Student Achievement Effects across Seven States. Econ. Educ. Rev. 31 (2), 213-224.

Zimmer, R., Gill, B., Attridge, J., Obenauf, K., 2014. Charter School Authorizers and Student Achievement. Educ. Financ. Policy. 9 (1), 59-85. 
Table 1: Survey of papers using administrative education data. Unmatched administrative source studies.

(1)

\begin{tabular}{|c|c|}
\hline Country/region & Authors, publication year and title \\
\hline Austria: Linz & $\begin{array}{l}\text { Schneeweis and Zweimuller (2012): “Girls, Girls, Girls: Gender } \\
\text { Composition and Female School Choice. }\end{array}$ \\
\hline England & $\begin{array}{l}\text { Machin, McNally and Silva (2007) New Technology in Schools: Is } \\
\text { There a Payoff? }\end{array}$ \\
\hline England & Ray, McCormack and Evans (2009) Value Added in English Schools. \\
\hline England & $\begin{array}{l}\text { Dustmann, Machin and Schonberg (2010) Ethnicity and Educational } \\
\text { Achievement in Compulsory Schooling. }\end{array}$ \\
\hline England & $\begin{array}{l}\text { Holmlund, McNally and Viarengo (2010) Does Money Matter for } \\
\text { Schools? }\end{array}$ \\
\hline England & $\begin{array}{l}\text { Burgess and Briggs (2010) School Assignment, School Choice and } \\
\text { Social Mobility }\end{array}$ \\
\hline England & $\begin{array}{l}\text { Gibbons and Silva (2011) Faith Primary Schools: Better Schools or } \\
\text { Better Pupils? }\end{array}$ \\
\hline England & Gibbons and Telhaj (2011) Pupil Mobility and School Disruption \\
\hline England & $\begin{array}{l}\text { Keslair, Maurin and McNally (2012) Every Child Matters? An } \\
\text { Evaluation of "Special Educational Needs" Programmes in England. }\end{array}$ \\
\hline England & $\begin{array}{l}\text { Lavy, Silva and Weinhardt (2012) The Good, the Bad, and the } \\
\text { Average: Evidence on Ability Peer Effects in Schools }\end{array}$ \\
\hline England and & Burgess, Wilson and Worth (2013) A Natural Experiment in School \\
\hline Wales & $\begin{array}{l}\text { Accountability: The Impact of School Performance Information on } \\
\text { Pupil Progress }\end{array}$ \\
\hline England & $\begin{array}{l}\text { Burgess and Greaves (2013) Test Scores, Subjective Assessment, and } \\
\text { Stereotyping of Ethnic Minorities. }\end{array}$ \\
\hline England & $\begin{array}{l}\text { Geay, McNally and Telhaj (2013) Non-Native Speakers of English in } \\
\text { the Classroom: What Are the Effects on Pupil Performance? }\end{array}$ \\
\hline England & $\begin{array}{l}\text { Gibbons, Silva and Weinhardt (2013) Everybody Needs Good } \\
\text { Neighbours? Evidence from Students' Outcomes in England. }\end{array}$ \\
\hline England & $\begin{array}{l}\text { Allen and Burgess (2013) Evaluating the Provision of School } \\
\text { Performance Information for School Choice. }\end{array}$ \\
\hline England & $\begin{array}{l}\text { Almond, Mazumder and Van Ewijk (2014) In Utero Ramadan } \\
\text { Exposure and Children's Academic Performance. }\end{array}$ \\
\hline Finland & $\begin{array}{l}\text { Hakkinen, Kirjavainen and Uusitalo (2003) School Resources and } \\
\text { Student Achievement Revisited: New Evidence from Panel Data. }\end{array}$ \\
\hline Germany: Hesse & $\begin{array}{l}\text { Muhlenweg and Puhani (2010) The Evolution of the School-Entry } \\
\text { Age Effect in a School Tracking System }\end{array}$ \\
\hline Italy & $\begin{array}{l}\text { Barbieri, Rossetti and Sestito (2011) The Determinants of Teacher } \\
\text { Mobility: Evidence Using Italian Teachers' Transfer Applications. }\end{array}$ \\
\hline Italy & $\begin{array}{l}\text { Angrist, Battistin and Vuri (2014) Is a Small Moment: Class Size and } \\
\text { Moral Hazard in the Mezzogiorno. }\end{array}$ \\
\hline Israel: Jerusalem & $\begin{array}{l}\text { Angrist and Lavy (2001) Does Teacher Training Affect Pupil } \\
\text { Learning? Evidence from Matched Comparisons in Jerusalem Public } \\
\text { Schools }\end{array}$ \\
\hline
\end{tabular}


Israel

Israel

Israel

Israel

Israel

Israel

Netherlands

Netherlands:

Rotterdam

Sweden

Canada: British

Columbia

Canada: British

Columbia

Canada: British

Columbia

Canada: British

Columbia

Canada: British

Columbia

Canada: Ontario

Canada: Ontario

Trinidad and

Tobago

Trinidad and

Tobago

Trinidad and

Tobago

USA: Alaska
Gould, Lavy and Paserman (2004) Immigrating to Opportunity:

Estimating the Effect of School Quality Using a Natural Experiment on Ethiopians in Israel

Lavy and Schlosser (2005) Targeted Remedial Education for Underperforming Teenagers: Costs and Benefits.

Lavy (2008) Do Gender Stereotypes Reduce Girls' or Boys' Human

Capital Outcomes? Evidence from a Natural Experiment.

Gould, Lavy and Paserman (2009) Does Immigration Affect the

Long-Term Educational Outcomes of Natives? Quasi-Experimental

Evidence.

Lavy and Paserman (2012) Inside The Black Box of Ability Peer

Effects: Evidence from Variation in the Proportion of Low Achievers in the Classroom.

Cohen-Zada, Gradstein and Reuven (2013) Allocation of Students in Public Schools: Theory and New Evidence.

Leuven et al. (2007) The Effect of Extra Funding for Disadvantaged Pupils on Achievement

Heers et al. (2014) The Impact of Community Schools on Student Dropout in Pre-Vocational Education.

Waldo (2007) On the Use of Student Data in Efficiency Analysis-

Technical Efficiency in Swedish Upper Secondary School.

Bedard and Dhuey (2006) The Persistence of Early Childhood

Maturity: International Evidence of Long-Run Age Effects

Smith (2010) How Valuable Is the Gift of Time? The Factors That

Drive the Birth Date Effect in Education.

Friesen, Hickey and Krauth (2010) Disabled Peers and Academic

Achievement.

Coelli and Green (2012) Leadership Effects: School Principals and

Student Outcomes.

DeCicca and Smith (2013) The Long-Run Impacts of Early

Childhood Education: Evidence from a Failed Policy Experiment

Card, Dooley and Payne (2010) School Competition and Efficiency

with Publicly Funded Catholic Schools.

Leach, Payne and Chan (2010) The Effects of School Board

Consolidation and Financing on Student Performance.

Jackson (2010) Do Students Benefit from Attending Better Schools?

Evidence from Rule-Based Student Assignments in Trinidad and

Tobago

Jackson (2012) Single-Sex Schools, Student Achievement, and

Course Selection: Evidence from Rule-Based Student Assignments in Trinidad and Tobago.

Jackson (2013) Can Higher-Achieving Peers Explain the Benefits to Attending Selective Schools? Evidence from Trinidad and Tobago.

Tuck, Berman and Hill (2009) Local Amenities, Unobserved Quality, and Market Clearing: Adjusting Teacher Compensation to Provide Equal Education Opportunities. 


\begin{tabular}{|c|c|}
\hline USA: California & $\begin{array}{l}\text { Clark, Rothstein and Schanzenbach (2009) Selection Bias in College } \\
\text { Admissions Test Scores. }\end{array}$ \\
\hline $\begin{array}{l}\text { USA: California } \\
\text { (San Diego) }\end{array}$ & $\begin{array}{l}\text { Koedel (2009) An Empirical Analysis of Teacher Spillover Effects in } \\
\text { Secondary School. }\end{array}$ \\
\hline USA: California & Jepsen (2010) Bilingual Education and English Proficiency \\
\hline USA: California & Koedel and Betts (2010) Value Added to What? How a Ceiling in the \\
\hline (San Diego) & Testing Instrument Influences Value-Added Estimation. \\
\hline USA: California & Koedel and Betts (2011) Does Student Sorting Invalidate Value- \\
\hline (San Diego) & $\begin{array}{l}\text { Added Models of Teacher Effectiveness? An Extended Analysis of } \\
\text { the Rothstein Critique }\end{array}$ \\
\hline USA: California & Zimmer et al. (2012) Examining Charter Student Achievement \\
\hline (San Diego) & Effects across Seven States. \\
\hline USA: Colorado & $\begin{array}{l}\text { Briggs and Weeks (2009) The Sensitivity of Value-Added Modeling } \\
\text { to the Creation of a Vertical Score Scale. }\end{array}$ \\
\hline $\begin{array}{l}\text { USA: Colorado } \\
\text { (Denver) }\end{array}$ & $\begin{array}{l}\text { Goldhaber and Walch (2012) Strategic Pay Reform: A Student } \\
\text { Outcomes-Based Evaluation of Denver's Procomp Teacher Pay } \\
\text { Initiative. }\end{array}$ \\
\hline USA: Colorado & Zimmer et al. (2012) Examining Charter Student Achievement \\
\hline (Denver) & Effects across Seven States. \\
\hline $\begin{array}{l}\text { USA: District } \\
\text { Columbia }\end{array}$ & $\begin{array}{l}\text { Curto and Fryer (2014) The Potential of Urban Boarding Schools for } \\
\text { the Poor: Evidence from SEED }\end{array}$ \\
\hline USA: Florida & $\begin{array}{l}\text { Figlio and Lucas (2004) What's in a Grade? School Report Cards and } \\
\text { the Housing Market }\end{array}$ \\
\hline USA: Florida & $\begin{array}{l}\text { Tyler, Murnane and Willett (2004) The Devil's in the Details: } \\
\text { Evidence from the GED on Large Effects of Small Differences in } \\
\text { High Stakes Exams. }\end{array}$ \\
\hline USA: Florida & $\begin{array}{l}\text { West and Peterson (2006) The Efficacy of Choice Threats within } \\
\text { School Accountability Systems: Results from Legislatively Induced } \\
\text { Experiments. }\end{array}$ \\
\hline USA: Florida & $\begin{array}{l}\text { Figlio and Rouse (2006) Do Accountability and Voucher Threats } \\
\text { Improve Low-Performing Schools? }\end{array}$ \\
\hline USA: Florida & Sass (2006) Charter Schools and Student Achievement in Florida \\
\hline USA: Florida & $\begin{array}{l}\text { Greene and Winters (2007) Revisiting Grade Retention: An } \\
\text { Evaluation of Florida's Test-Based Promotion Policy. }\end{array}$ \\
\hline USA: Florida & $\begin{array}{l}\text { McCaffrey et al. (2009) The Intertemporal Variability of Teacher } \\
\text { Effect Estimates. }\end{array}$ \\
\hline USA: Florida & $\begin{array}{l}\text { Greene and Winters (2009) The Effects of Exemptions to Florida's } \\
\text { Test-Based Promotion Policy: Who Is Retained? Who Benefits } \\
\text { Academically? }\end{array}$ \\
\hline USA: Florida & $\begin{array}{l}\text { Chiang (2009) How Accountability Pressure on Failing Schools } \\
\text { Affects Student Achievement }\end{array}$ \\
\hline USA: Florida & $\begin{array}{l}\text { Winters, Trivitt and Greene (2010) The Impact of High-Stakes } \\
\text { Testing on Student Proficiency in Low-Stakes Subjects: Evidence } \\
\text { from Florida's Elementary Science Exam. }\end{array}$ \\
\hline USA: Florida & $\begin{array}{l}\text { Feng (2010) Hire Today, Gone Tomorrow: New Teacher Classroom } \\
\text { Assignments and Teacher Mobility }\end{array}$ \\
\hline
\end{tabular}


USA: Florida

USA: Florida

USA: Florida

USA: Florida

USA: Florida

USA: Florida

USA: Florida

USA: Florida

USA: Florida

USA: Florida

USA: Florida

USA: Florida

USA: Florida

USA: Florida

USA: Florida

USA: Florida (Miami-Dade) USA: Florida (Miami-Dade) USA: Illinois

USA: Illinois USA: Illinois (Chicago)
Harris and Sass (2011) Teacher Training, Teacher Quality and Student Achievement.

Booker et al. (2011) The Effects of Charter High Schools on Educational Attainment

Chingos and Peterson (2011) It's Easier to Pick a Good Teacher Than to Train One: Familiar and New Results on the Correlates of Teacher Effectiveness.

Chingos (2012) The Impact of a Universal Class-Size Reduction Policy: Evidence from Florida's Statewide Mandate.

Winters, Dixon and Greene (2012) Observed Characteristics and Teacher Quality: Impacts of Sample Selection on a Value Added Model.

Winters and Greene (2012) The Medium-Run Effects of Florida's Test-Based Promotion Policy

Weiss and May (2012) A Policy Analysis of the Federal Growth Model Pilot Program's Measures of School Performance: The Florida Case.

Schwerdt and West (2013) The Impact of Alternative Grade Configurations on Student Outcomes through Middle and High School.

Mihaly et al. (2013) Where You Come from or Where You Go?

Distinguishing Between School Quality and the Effectiveness of Teacher Preparation Program Graduates.

Feng and Sass (2013) What Makes Special-Education Teachers Special? Teacher Training and Achievement of Students with Disabilities.

Winters et al. (2013) The Effect of Same-Gender Teacher Assignment on Student Achievement in the Elementary and Secondary Grades: Evidence from Panel Data.

Burke and Sass (2013) Classroom Peer Effects and Student Achievement

Cowen and Winter (2013) Do Charters Retain Teachers Differently?

Evidence from Elementary Schools in Florida

Figlio and Hart (2014) Competitive Effects of Means-Tested School Vouchers.

Sass, Semykina and Harris (2014) Value-Added Models and the Measurement of Teacher Productivity Taylor (2014) Spending More of the School Day in Math Class: Evidence from a Regression Discontinuity in Middle School Loeb, Kalogrides and Beteille (2012) Effective Schools: Teacher Hiring, Assignment, Development, and Retention Fitzpatrick and Lovenheim (2014) Early Retirement Incentives and Student Achievement. Gates et al. (2006) Mobility and Turnover Among School Principals. Cullen, Jacob and Levitt (2006) The Effect of School Choice on Participants: Evidence from Randomized Lotteries 
USA: Illinois

(Chicago)

USA: Illinois

(Chicago)

USA: Illinois

(Chicago)

USA: Illinois

(Chicago)

USA: Illinois

(Chicago)

USA: Illinois

(Chicago)

USA: Illinois

(Chicago)

USA: Illinois

(Chicago)

USA: Illinois

(Chicago)

USA: Illinois

(Chicago)

USA: Illinois

(Chicago)

USA: Illinois

(Chicago)

USA: Illinois

(Chicago)

USA: Illinois

(Chicago)

USA: Illinois

(Chicago)

USA: Kentucky

USA: Kentucky

USA: Kentucky

USA: Kentucky

USA: Louisiana

USA: Louisiana

USA:
Jacob and Levitt (2003) Rotten Apples: an Investigation of the Prevalence and Predictors of Teacher Cheating Neal and Schanzenbach (2010) Left Behind by Design: Proficiency Counts and Test-Based Accountability Jacob and Lefgren (2004) Remedial Education and Student Achievement: A Regression-Discontinuity Analysis Jacob and Lefgren (2004) The Impact of Teacher Training on Student Achievement: Quasi-Experimental Evidence from School Reform Efforts in Chicago

Booker (2011) The Effects of Charter High Schools on Educational Attainment

Jacob (2013) The Effect of Employment Protection on Teacher Effort

Aaronson, Barrow and Sander (2007) Teachers and Student

Achievement in the Chicago Public High Schools.

Jacob and Lefgren (2009) The Effect of Grade Retention on High

School Completion

Jacob (2005) Accountability, Incentives and Behavior: the Impact of High-Stakes Testing in the Chicago Public Schools

Cullen, Jacob and Levitt (2005) The Impact of School Choice on

Student Outcomes: An Analysis of the Chicago Public Schools.

Steinberg (2014) Does Greater Autonomy Improve School

Performance? Evidence from a Regression Discontinuity Analysis in

Chicago.

Cortes, Moussa and Weinstein (2013) Educating Bright Students in

Urban Schools.

Jacob and Walsh (2011) What's in a Rating?

Robertson (2011) The Effects of Quarter of Birth on Academic Outcomes at the Elementary School Level

Cortes, Goodman and Nomi (2014) Intensive Math Instruction and Educational Attainment: Long-Run Impacts of Double-Dose Algebra.

Streams et al. (2011) School Finance Reform: Do Equalized

Expenditures Imply Equalized Teacher Salaries?

Barrett and Toma (2013) Reward or Punishment? Class Size and

Teacher Quality

Cowen et al. (2012) Teacher Retention in Appalachian Schools:

Evidence from Kentucky

Kukla-Acevedo (2009) Do Teacher Characteristics Matter? New

Results on the Effects of Teacher Preparation on Student

Achievement.

Imberman, Kugler and Sacerdote (2012) Katrina's Children: Evidence on the Structure of Peer Effects from Hurricane Evacuees

Sacerdote (2012) When the Saints Go Marching Out: Long-Term Outcomes for Student Evacuees from Hurricanes Katrina and Rita. Goodman (2008) Who Merits Financial Aid?: Massachusetts' Adams 


\begin{tabular}{|c|c|}
\hline Massachusetts & holarship. \\
\hline USA: & Joodman (2010) Skills, Schools, and Credit Constraints: Evidence \\
\hline Massachusetts & rom Massachusetts \\
\hline USA: & Goodman (2014) Flaking Out: Student Absences and Snow Days as \\
\hline Massachusetts & Disruptions of Instructional Time. \\
\hline USA: & Abdulkadiroglu, Pathak and Roth (2009) Strategy-Proofness versus \\
\hline Massachusetts & Efficiency in Matching with Indifferences: Redesigning the NYC \\
\hline (Boston) & High School Match \\
\hline USA: & Angrist and Lang (2004) Does School Integration Generate Peer \\
\hline $\begin{array}{l}\text { Massachusetts } \\
\text { (Brookline) }\end{array}$ & Effects? Evidence from Boston's Metco Program \\
\hline USA: & Ibdulkadiroglu, Angrist and Pathak (2014) The Elite Illusion: \\
\hline $\begin{array}{l}\text { Massachusetts } \\
\text { (Boston) }\end{array}$ & Achievement Effects at Boston and New York Exam Schools. \\
\hline USA: & Abdulkadiroglu et al. (2011) Accountability and Flexibility in Public \\
\hline $\begin{array}{l}\text { Massachusetts } \\
\text { (Boston) }\end{array}$ & Schools: Evidence from Boston's Charters and Pilots \\
\hline USA: & athak and Shi (2014) Demand Modeling, Fore \\
\hline $\begin{array}{l}\text { Massachusetts } \\
\text { (Boston) }\end{array}$ & Counterfactuals, Part I \\
\hline USA: Michigan & $\begin{array}{l}\text { Gershenson (2012) How Do Substitute Teachers Substitute? An } \\
\text { Empirical Study of Substitute-Teacher Labor Supply }\end{array}$ \\
\hline USA: Michigan & $\begin{array}{l}\text { Andrews, DesJardins and Ranchhod (2010) The Effects of the } \\
\text { Kalamazoo Promise on College Choice. }\end{array}$ \\
\hline USA: Michigan & $\begin{array}{l}\text { Brummet (2014) The Effects of School Closings on Student } \\
\text { Achievement. }\end{array}$ \\
\hline USA: Minnesota & Hinrichs (2011) When the Bell Tolls: The Effects of School Starting \\
\hline (Twin Citie & Times on Academic Ac \\
\hline USA: Missouri & $\begin{array}{l}\text { Ransom and Sims (2010) Estimating the Firm's Labor Supply Curve } \\
\text { in a "New Monopsony" Framework: Schoolteachers in Missouri. }\end{array}$ \\
\hline USA: Missouri & $\begin{array}{l}\text { Koedel, Ni and Podgursky (2014) Who Benefits From Pension } \\
\text { Enhancements? }\end{array}$ \\
\hline USA: Missouri & $\begin{array}{l}\text { Costrell and Podgursky (2010) Distribution of Benefits in Teacher } \\
\text { Retirement Systems and Their Implications for Mobility }\end{array}$ \\
\hline JSA: North & Rothstein (2010) Teacher Quality in Educational Production: \\
\hline Carolina & Tracking, Decay, and Student Achievement \\
\hline USA: North & Jackson (2013) Worker Productivity, and Worker Mobility: Direct \\
\hline Carolina & Evidence from Teachers \\
\hline USA: North & Fruehwirth (2014) Can Achievement Peer Effect Estimates Inform \\
\hline Carolina & Policy? A View from Inside the Black Box. \\
\hline USA: North & Clotfelter, Ladd and Vigdor (2009) The Academic Achievement Ga \\
\hline Carolina & \\
\hline USA: North & Kinsler (2012) Beyond Levels and Growth: Estimating Teacher \\
\hline Carolina & Value-Added and its Persistence. \\
\hline USA: North & Goldhaber (2007) Everyone's Doing It, But What Does Teacher \\
\hline Carolina & Testing Tell Us About Teacher Effectiveness? \\
\hline
\end{tabular}


USA: North

Carolina

USA: North

Carolina

USA: North

Carolina

USA: North

Carolina

USA: North

Carolina

USA: North

Carolina

USA: North

Carolina

USA: North

Carolina

USA: North

Carolina

USA: North

Carolina

USA: North

Carolina

USA: North

Carolina

USA: North

Carolina

USA: North

Carolina

USA: North

Carolina

USA: North

Carolina

USA: North

Carolina

USA: North

Carolina

USA: North

Carolina

USA: North

Carolina

USA: North

Carolina

USA: North

Carolina
Clotfelter, Ladd and Vigdor (2009) Teacher Credentials and Student

Achievement in High School: A Cross-Subject Analysis with Student Fixed Effects.

Jacob, Lefgren and Sims (2010) The Persistence of Teacher-Induced

Learning

Clotfelter, Ladd, Vigdor (2006) Teacher-Student Matching and the

Assessment of Teacher Effectiveness

Murnane and Olsen (1990) The Effects of Salaries and Opportunity

Costs on Length of Stay in Teaching: Evidence from North Carolina

Jackson (2009) Student Demographics, Teacher Sorting, and Teacher

Quality: Evidence from the End of School Desegregation.

Jackson and Bruegmann (2009) Teaching Students and Teaching

Each Other: The Importance of Peer Learning for Teachers

Ost (2014) How Do Teachers Improve? The Relative Importance of

Specific and General Human Capital.

Jackson (2012) School Competition and Teacher Labor Markets:

Evidence from Charter School Entry in North Carolina.

Wiswall (2013) The Dynamics of Teacher Quality.

Clotfelter et al. (2008) Would Higher Salaries Keep Teachers in

High-Poverty Schools? Evidence from a Policy Intervention in North Carolina.

Henry et al. (2014) Teacher Preparation Policies and their Effects on

Student Achievement.

Fuller and Ladd (2013) School-Based Accountability and the

Distribution of Teacher Quality across Grades in Elementary School.

Carruthers (2012) The Qualifications and Classroom Performance of

Teachers Moving to Charter Schools.

Clotfelter, Ladd and Vigdro (2011) Teacher Mobility, School

Segregation, and Pay-Based Policies to Level the Playing Field.

Player (2010) Nonmonetary Compensation in the Public Teacher

Labor Market

Bifulco and Ladd (2006) The Impacts of Charter Schools on Student

Achievement: Evidence from North Carolina.

Rothstein (2009) Student Sorting and Bias in Value-Added

Estimation: Selection on Observables and Unobservables.

Clotfelter, Ladd and Vigdor (2009) Are Teacher Absences Worth

Worrying about in the United States?

Condie, Lefgren and Sims (2014) Teacher Heterogeneity, Value-

Added and Education Policy

Ahn (2014) A Regression Discontinuity Analysis of Graduation

Standards and Their Impact on Students' Academic Trajectories.

Miller (2013) Principal Turnover and Student Achievement.

Strain (2013) Single-Sex Classes \& Student Outcomes: Evidence from North Carolina. 
USA: North

Carolina

USA: North

Carolina

USA: North

Carolina

USA: North

Carolina

USA: North

Carolina

USA: North

Carolina

USA: North

Carolina

USA: North

Carolina

USA: North

Carolina

USA: North

Carolina

USA: North

Carolina

USA: North

Carolina

USA: North

Carolina

USA: North

Carolina

USA: North

Carolina

(Charlotte-

Mecklenburg)

USA: North

Carolina (Wake)

USA: North

Carolina (Wake)

USA: North

Carolina (Wake)

USA: North

Carolina

(Wayne)

USA: New
Goldhaber, Cowen and Walch (2013) Is a Good Elementary Teacher Always Good? Assessing Teacher Performance Estimates across

Subjects

Cratty (2012) Potential for Significant Reductions in Dropout Rates:

Analysis of an Entire 3rd Grade State Cohort.

Miller and Mittleman (2012) High Schools That Work and College

Preparedness: Measuring the Model's Impact on Mathematics and

Science Pipeline Progression

Carruthers (2012) New Schools, New Students, New Teachers:

Evaluating the Effectiveness of Charter Schools.

Kinsler (2011) Understanding the Black-White School Discipline

Gap.

Guardiano, Brown and Wyse (2011) Can Districts Keep Good

Teachers in the Schools That Need Them Most?

Clotfelter, Ladd and Vigdor (2007) Teacher Credentials and Student Achievement: Longitudinal Analysis with Student Fixed Effects.

Gates et al. (2006) Mobility and Turnover Among School Principals.

Clotfelter, Ladd and Vigdor (2005) Who Teaches Whom? Race and the Distribution of Novice Teachers.

Ladd and Walsh (2002) Implementing Value-Added Measures of

School Effectiveness: Getting the Incentives Right.

Jackson (2014) Teacher Quality at the High-School Level: The

Importance of Accounting for Tracks

Mansfield (2014) Teacher Quality and Student Inequality

Ahn and Vigdor (2014) When Incentives Matter Too Much:

Explaining Significant Responses to Irrelevant Information.

Macartney (2014) The Dynamic Effects of Educational

Accountability

Deming (2014) Using School Choice Lotteries to Test Measures of

School Effectiveness.

Edwards (2012) Early to Rise? The Effect of Daily Start Times on Academic Performance.

McMullen and Rouse (2012) School Crowding, Year-Round

Schooling, and Mobile Classroom Use: Evidence from North

Carolina.

McMullen and Rouse (2012) The Impact of Year-Round Schooling

on Academic Achievement: Evidence from Mandatory School

Calendar Conversions

Bastian, Henry and Thompson (2013) Incorporating Access to More

Effective Teachers into Assessments of Educational Resource Equity.

Ou (2010) To Leave or not to Leave? A Regression Discontinuity 
Jersey

USA: New York

USA: New York

USA: New York

USA: New York

(New York City)

USA: New York

(New York City)

USA: New York

(New York City)

USA: New York

(New York City)

USA: New York

(New York City)

USA: New York

(New York City)

USA: New York

(New York City)

USA: New York

(New York City)

USA: New York

(New York City)

USA: New York

(New York City)

USA: New York

(New York City)

USA: New York

(New York City)

USA: Ohio

USA: Ohio

USA: Ohio

(Cincinnati)

USA: Ohio

(Cincinnati)

USA:

Pennsylvania
Analysis of the Impact of Failing the High School Exit Exam.

Boyd et al. (2013) Analyzing the Determinants of the Matching of

Public School Teachers to Jobs: Disentangling the Preferences of

Teachers and Employers

Brewer (1996) Career Paths and Quit Decisions: Evidence from

Teaching

Lankford and Wyckoff (1997) The Changing Structure of Teacher

Compensation, 1970-94.

Abdulkadiroglu, Pathak and Roth (2009) Strategy-Proofness versus

Efficiency in Matching with Indifferences: Redesigning the NYC

High School Match

Abdulkadiroglu, Angrist and Pathak (2009)The Elite Illusion:

Achievement Effects at Boston and New York Exam Schools.

Schwartz, Stiefel and Kim (2004) The Impact of School Reform on

Student Performance: Evidence From the New York Network for

School Renewal Project

Hermann and Rockoff (2012) Worker Absence and Productivity:

Evidence from Teaching

Rockoff and Lockwood (2010) Stuck in the Middle: Impacts of Grade Configuration in Public Schools.

Zabel (2008) The Impact of Peer Effects on Student Outcomes in

New York City Public Schools

Schwartz and Stiefel (2006) Is There a Nativity Gap? New Evidence

on the Academic Performance of Immigrant Students.

Rubenstein et al. (2009) Spending, Size, and Grade Span in K-8

Schools.

Wiswall et al. (2014) Does Attending a STEM High School Improve

Student Performance? Evidence from New York City.

Leos-Urbel et al. (2013) Not Just for Poor Kids: The Impact of

Universal Free School Breakfast on Meal Participation and Student

Outcomes.

Winters (2012) Measuring the Effect of Charter Schools on Public

School Student Achievement in an Urban Environment: Evidence from New York City.

Kane, Rockoff and Staiger (2008) What Does Certification Tell Us

About Teacher Effectiveness? Evidence from New York City.

Zimmer et al. (2014) Charter School Authorizers and Student

Achievement

Zimmer et al. (2014) Examining Charter Student Achievement

Effects across Seven States.

Taylor and Tyler (2012) The Effect of Evaluation on Teacher

Performance.

Kane et al. (2011) Identifying Effective Classroom Practices Using

Student Achievement Data.

Ferguson, Strauss and Vogt (2006) The Effects of Defined Benefit

Pension Incentives and Working Conditions on Teacher Retirement 
USA:

Pennsylvania

(Philadelphia)

USA: Texas

USA: Texas

USA: Texas

USA: Texas

USA: Texas

USA: Texas

USA: Texas

USA: Texas

USA: Texas

USA: Texas

USA: Texas

USA: Texas

USA: Texas

USA: Texas

USA: Texas

USA: Texas

USA: Texas

USA: Texas (Houston)

USA: Texas (Houston)

USA: Utah
Decisions

Zimmer et al. (2012) Examining Charter Student Achievement Effects across Seven States.

Cullen, Long and Reback (2013) Jockeying for Position: Strategic High School Choice under Texas' Top Ten Percent Plan.

Reback (2008) Teaching to the Rating: School Accountability and the Distribution of Student Achievement.

Booker et al. (2007) The Impact of Charter School Attendance on Student Performance.

Hanushek et al. (2007) Charter School Quality and Parental Decision Making with School Choice.

Hanushek, Kain and Rivkin (2004) Disruption Versus Tiebout Improvement: The Costs and Benefits of Switching Schools.

Clark, Rothstein and Schanzenbach (2009) Selection Bias in College Admissions Test Scores.

Hanushek, Kain and Rivkin (2004) Why Public Schools Lose

Teachers

Hendricks (2014) Does it Pay to Pay Teachers More? Evidence from Texas.

Rivkin, Hanushek and Kain (2005) Teachers, Schools, and Academic Achievement.

Currie et al. (2009) Does Pollution Increase School Absences?

Hanushek, Kain and Rivkin (2002) Inferring Program Effects for

Special Populations: Does Special Education Raise Achievement for Students With Disabilities?

Sanders (2012) What Doesn't Kill You Makes You Weaker. Prenatal Pollution Exposure and educational Outcomes

Hanushek, Kain and Rivkin (2009) New Evidence about Brown v.

Board of Education: The Complex Effects of School Racial

Composition on Achievement.

Zimmer (2012) Examining Charter Student Achievement Effects across Seven States.

Tyler and Lofstrom (2010) Is the GED an Effective Route to

Postsecondary Education for School Dropouts?

Tyler, Murnane and Willett (2004) The Devil's in the Details:

Evidence from the GED on Large Effects of Small Differences in

High Stakes Exams.

Klopfenstein (2004) Advanced Placement: Do Minorities Have Equal Opportunity?

Imberman and Lovenheim (2015) Incentive Strength and Teacher Productivity: Evidence from a Group-Based Teacher Incentive Pay System

Imberman, Kugler and Sacerdote (2012) Katrina's Children: Evidence on the Structure of Peer Effects from Hurricane Evacuees

Ni and Rorrer (2012) Twice Considered: Charter Schools and Student 

USA:
Washington
USA:
Washington
USA:
Washington
USA:
Washington
USA:
Washington
USA:
Washington
USA:
Washington
USA:
Washington
USA: Wisconsin
USA: Wisconsin
(Milwaukee)
USA: unnamed
USA: unnamed
USA: unnamed
USA: unnamed
USA: unnamed
USA: unnamed
USA: unnamed
USA
Chile
Chile
Chile
Theobald and Gritz (1996) The Effects of School District Spending Priorities on Length of Stay in Teaching.
Goldhaber and Theobald (2013) Managing the Teacher Workforce in
Austere Times: The Determinants and Implications of Teacher Layoffs
Krieg (2008) Are Students Left Behind? The Distributional Effects of the No Child Left Behind Act.
Goldhaber, Liddle and Theobald (2013) The Gateway to the
Profession: Assessing Teacher Preparation Programs Based on
Student Achievement
Krieg (2011) Which Students Are Left Behind? The Racial Impacts of the No Child Left Behind Act.
Krieg (2006) Teacher Quality and Attrition.
Theobald and Gritz (1996) The Effects of School District Spending
Priorities on the Exit Paths of Beginning Teachers Leaving the
District.
Theobald (1990) An Examination of the Influence of Personal, Professional, and School District Characteristics on Public School Teacher Retention.
Teacher Salaries and Teacher Attrition.
Examining Charter Student Achievement Effects across Seven States.
Springer (2008) The Influence of an NCLB Accountability Plan on the Distribution of Student Test Score Gains.
Matsudaira, Hosek and Walsh (2012) An Integrated Assessment of the Effects of Title I on School Behavior, Resources, and Student Achievement.
Imberman (2011) The Effect of Charter Schools on Achievement and Behavior of Public School Students.
Bui, Craig and Imberman (2014) Is Gifted Education a Bright Idea? Assessing the Impact of Gifted and Talented Programs on Students. Lockwood and McCaffrey (2009) Exploring Student-Teacher Interactions in Longitudinal Achievement Data.
Engberg (2014) Evaluating Education Programs That Have Lotteried Admission and Selective Attrition.
Imberman (2011) Achievement and Behavior in Charter Schools: Drawing a More Complete Picture.
Belfield and Levin (2004) Should High School Economics Courses
Be Compulsory?
Urquiola and Verhoogen (2009) Class-Size Caps, Sorting, and the Regression-Discontinuity Design
Mizal and Roumaguera (2000) School Performance and Choice: The Chilean Experience
Thieme, Prior and Tortosa-Ausina (2013) A Multilevel

Achievement in Utah 
Decomposition of School Performance Using Robust Nonparametric Frontier Techniques

Chile Bellei (2009) Does Lengthening the School Day Increase Students' Academic Achievement? Results from a Natural Experiment in Chile.

Peru Dell (2010) The Persistent Effects of Peru's Mining Mita

China: Beijing Lai (2010) Are Boys Left Behind? The Evolution of the Gender Achievement Gap in Beijing's Middle Schools.

Kenya $\quad$ Lucas and Mbiti (2014) Effects of School Quality on Student

Achievement: Discontinuity Evidence from Kenya

Australia: $\quad$ Leigh (2010) Estimating Teacher Effectiveness from Two-Year

Queensland Changes in Students' Test Scores.

Note: This table lists studies which make use of unmatched administrative data, and that have been published or announced as forthcoming between January 1990 and July 2014 in the following outlets: American Economic Journal: Applied Economics, American Economic Journal: Economic Policy, American Economic Review, Econometrica, Economic Journal, Economics of Education Review, Education Finance and Policy, Journal of Human Resources, Journal of Labor Economics, Journal of Political Economy, Journal of Public Economics, Quarterly Journal of Economics, Review of Economic Studies, Review of Economics and Statistics and NBER Working Papers: Education Program. All the papers in the table used at least one administrative data set in the analysis and these data were not matched across registers or to other external data sources. 
Table 2: Survey of papers using administrative education data. Multiple matched administrative sources studies.

(1) (2)

Country/region Authors, publication year and title

Denmark Heinesen (2009): Estimating Class-Size Effects using WithinSchool Variation in Subject-Specific Classes.

Denmark Damm and Dustmann (2014) Does Growing Up in a High Crime Neighborhood Affect Youth Criminal Behavior?

Finland Kerr, Pekkarinen and Uusitalo (2013) School Tracking and Development of Cognitive Skills.

Germany: Hesse, Dustmann and Schonberg (2012) Expansions in Maternity Leave

Bayern, Coverage and Children's Long-Term Outcomes.

Schleswig-

Holstein

Norway

Falch and Strom (2005) Teacher Turnover and Non-Pecuniary Factors.

Norway Black, Devereux and Salvanes (2005) The More the Merrier? The Effect of Family Size and Birth Order on Children's Education

Norway Black, Devereux and Salvanes (2005) Why the Apple Doesn't Fall Far: Understanding Intergenerational Transmission of Human Capital

Norway Black, Devereux and Salvanes (2007) From the Cradle to the Labor Market? The Effect of Birth Weight on Adult Outcomes

Norway Black, Devereux and Salvanes (2010) Small Family, Smart Family? Family Size and the IQ Scores of Young Men

Norway Rege, Telle and Votruba (2011) Parental Job Loss and Children's School Performance

Norway Black, Devereux and Salvanes (2011) Too Young to Leave the Nest? The Effects Of School Starting

Norway Havnes and Mogstad (2011) No Child Left Behind: Subsidized Child Care and Children's Long-Run Outcomes.

Norway Haegeland, Raaum and Salvanes (2012) Pennies from Heaven? Using Exogenous Tax Variation to Identify Effects of School Resources on Pupil Achievement.

Norway Loken, Mogstad and Wiswall (2012) What Linear Estimators Miss: The Effects of Family Income on Child Outcomes.

Norway $\quad$ Falch and Naper (2013) Educational Evaluation Schemes and Gender Gaps in Student Achievement.

Norway Bharadwaj, Loken and Neilson (2013) Early Life Health Interventions and Academic Achievement

Norway Black, Devereux and Salvanes (2013) Under Pressure? The Effect of Peers on Outcomes of Young Adults

Norway Bettinger, Haegeland and Rege (2014) Home with Mom: The Effects of Stay-at-Home Parents on Children's Long-Run Educational Outcomes.

Norway Black, Devereux and Salvanes (2014) Does Grief Transfer Across 
Norway

Norway

Sweden

Sweden

Sweden

Sweden

Sweden:

Stockholm

Sweden

Sweden

Sweden

Sweden

Sweden

Sweden

Sweden

Canada: Manitoba

Canada: Manitoba

USA: Arkansas

USA: Florida

USA: Florida

USA: Florida

(Alachua)

USA: Florida
Generations? In-Utero Deaths and Child Outcomes.

Black et al. (2014) Care or Cash? The Effect of Child Care

Subsidies on Student Performance

Havens and Mogstad (2014) Is Universal Child Care Leveling the Playing Field.

Wikstrom and Wikstrom (2005) Grade Inflation and School

Competition: An Empirical Analysis Based on the Swedish Upper

Secondary Schools.

Sandstrom and Bergstrom (2005) School Vouchers in Practice:

Competition Will Not Hurt You.

Bjorklund, Lindahl and Plug (2006) The Origins of

Intergenerational Associations: Lessons from Swedish Adoption

Data

Almond, Edlund and Palme (2009) Chernobyl's Subclinical

Legacy: Prenatal Exposure to Radioactive Fallout and School

Outcomes in Sweden

Sund (2009) Estimating Peer Effects in Swedish High School Using

School, Teacher, and Student Fixed Effects

Chingos and West (2011) Do You Want Your Child to Have a

Certified Teacher?

Aslund et atl. (2011) Peers, Neighborhoods, and Immigrant Student

Achievement: Evidence from a Placement Policy

Hall (2012) The Effects of Reducing Tracking in Upper Secondary

School: Evidence from a Large-Scale Pilot Scheme.

Hensvik (2012) Competition, Wages and Teacher Sorting: Lessons

Learned from a Voucher Reform.

Gronqvist and Hall (2013) Education Policy and Early Fertility:

Lessons from an Expansion of Upper Secondary Schooling.

Fredriksson, Ockert and Oosterbeek (2013) Long-Term Effects of

Class Size

Lundborg, Nilsson and Rooth (2014) Parental Education and

Offspring Outcomes: Evidence from the Swedish Compulsory

School Reform.

Oreopoulos et al. (2008) Short-, Medium-, and Long-Term

Consequences of Poor Infant Health: An Analysis Using Siblings

and Twins

Currie et al. (2010) Child Health and Young Adult Outcomes

Costrell and McGee (2010) Teacher Pension Incentives, Retirement

Behavior, and Potential for Reform in Arkansas

Figlio (2007) Boys Named Sue: Disruptive Children and Their

Peers.

Figlio, Hart and Metzger (2010) Who Uses a Means-Tested

Scholarship, and What Do They Choose?

Carrell and Hoekstra (2010) Externalities in the Classroom: How

Children Exposed to Domestic Violence Affect Everyone's Kids.

Clark and See (2011) The Impact of Tougher Education Standards: 

USA: Florida
USA: Florida
USA: Florida
USA: Georgia
USA: Illinois
USA: Illinois
(Chicago)
USA: Illinois
(Chicago)
USA:
Massachusetts
USA: Missouri
USA: North
Carolina
USA: North
Carolina
USA: North
Carolina
USA: North
Carolina
(Charlotte-
Mecklenburg)
USA: North
Carolina
(Charlotte-
Mecklenburg)
USA: North
Carolina
(Charlotte-
Mecklenburg)
USA: North
Carolina
(Charlotte-
Mecklenburg)
Evidence from Florida.
Chingos and West (2011) Promotion and Reassignment in Public
School Districts: How Do Schools Respond to Differences in
Teacher Effectiveness?
Chingos and West (2012) Do More Effective Teachers Earn More
Outside the Classroom?
Figlio et al. (2014) The Effects of Poor Neonatal Health on
Children's Cognitive Development
Scafidi, Sjoquist and Stinebrickner (2007) Race, Poverty, and
Teacher Mobility.
Doyle (2007) Child Protection and Child Outcomes: Measuring the Effects of Foster Care
Jacob (2004) Public Housing, Housing Vouchers, and Student
Achievement: Evidence from Public Housing Demolitions in
Chicago
Cho (2009) The Impact of Maternal Imprisonment on Children's
Educational Achievement: Results from Children in Chicago Public
Schools.
Angrist, Pathak and Walters (2013) Explaining Charter School
Effectiveness
Podgursky, Monroe and Watson (2004) The Academic Quality of
Public School Teachers: An Analysis of Entry and Exit Behavior
Goldhaber and Anthony (2007) Can Teacher Quality Be Effectively
Assessed? National Board Certification as a Signal of Effective Teaching.
Goldhaber and Hansen (2009) National Board Certification and Teachers' Career Paths: Does NBPTS Certification Influence How Long Teachers Remain in The Profession and Where They Teach?
Goldhaber,Choi and Cramer (2007) A Descriptive Analysis of the
Distribution of NBPTS-Certified Teachers in North Carolina
Billings, Deming and Rockoff (2014) School Segregation,
Educational Attainment, and Crime: Evidence from the End of
Busing in Charlotte-Mecklenburg
Deming (2011) Better Schools, Less Crime?
Hastings et al. (2007) The Effect of Randomized School
Admissions on Voter Participation
Deming et al. (2013) School Choice, School Quality, and Postsecondary Attainment


USA: New York

(New York City)

USA: New York

(New York City)

USA: New York

(New York City)

USA: Texas

USA: Texas

USA: unnamed

USA: unnamed

USA: unnamed

USA

Taiwan
Dobbie and Fryer (2011) Are High-Quality Schools Enough to Increase Achievement Among the Poor? Evidence from the Harlem Children's Zone

Dobbie and Fryer (2014) The Impact of Attending a School with High-Achieving Peers: Evidence from the New York City Exam Schools.

Boyd et al. (2006) How Changes in Entry Requirements Alter the Teacher Workforce and Affect Student Achievement.

Clark and Martorell (2014) The Signaling Value of a High School Diploma

Lyle (2006) Using Military Deployments and Job Assignments to Estimate the Effect of Parental.

Chetty, Friedman and Rockoff (2014) Measuring the Impacts of Teachers I: Evaluating Bias in Teacher Value-Added Estimates Chetty, Friedman and Rockoff (2014) Measuring the Impacts of Teachers II: Teacher Value-Added and Student Outcomes in Adulthood

Engel, Gallagher and Lyle (2010) Military Deployments and Children's Academic Achievement: Evidence from Department of Defense Education Activity Schools.

Tyler, Murnane and Willett (2000) Estimating the Labor Market Signaling Value of the GED

Gimenez et al. (2013) Parental Loss and Children's Well-Being.

Note: This table lists studies which make use of administrative data matched across multiple registers, and that have been published or announced as forthcoming between January 1990 and July 2014 in the following outlets: American Economic Journal: Applied Economics, American Economic Journal: Economic Policy, American Economic Review, Econometrica, Economic Journal, Economics of Education Review, Education Finance and Policy, Journal of Human Resources, Journal of Labor Economics, Journal of Political Economy, Journal of Public Economics, Quarterly Journal of Economics, Review of Economic Studies, Review of Economics and Statistics and NBER Working Papers: Education Program. All the papers in the table used at least two administrative data sets in the analysis and these data sets were matched together. We excluded from this table studies that matched a single administrative data source to non-administrative external data sources such as surveys.

Table 3: Survey of papers using administrative education data. Unmatched administrative source studies matched to surveys or experiments.

(1)

Country/region

Authors, publication year and title 
France: Paris

Israel

Israel

Israel

Israel

Netherlands:

Amsterdam

Netherlands:

unnamed

Netherland:

Amsterdam

Romania

Sweden

Mexico

USA: California

USA: Colorado

(Denver)

USA: Florida

(Alachua)

USA: Florida

USA: Illinois

(Chicago)

USA: Illinois

(Chicago)

USA: Illinois

(Chicago)

USA: Indiana

(Gary)

USA: North

Carolina

(Charlotte-
Avvisati et al. (2014) Getting Parents Involved: A Field Experiment in Deprived Schools

Angrist and Lavy (2009) The Effects of High Stakes High School

Achievement Awards: Evidence from a Randomized Trial

Lavy (2009) Performance Pay and Teachers' Effort, Productivity, and Grading Ethics

Lavy and Schlosser (2011) Mechanisms and Impacts of Gender

Peer Effects at School

Lavy (2013) Gender Differences in Market Competitiveness in a

Real Workplace: Evidence from Performance-Based Pay

Tournaments among Teachers.

Cabus and De Witte (2011) Does School Time Matter? —On the

Impact of Compulsory Education Age on School Dropout.

Meyer and Van Klaveren (2013) The Effectiveness of Extended

Day Programs: Evidence from a Randomized Field Experiment in the Netherlands.

Buser, Niederle and Oosterbeek (2014) Gender, Competitiveness, and Career Choices

Pop-Eleches and Urquiola (2013) Going to a Better School: Effects and Behavioral Responses

Hinnerich, Hoglin and Johannesson (2011) Are Boys Discriminated in Swedish High Schools?

Behrman et al. (2014) Aligning Learning Incentives of Students and Teachers: Results from a Social Experiment in Mexican High Schools

Fairlie and Robinson (2013) Experimental Evidence on the Effects of Home Computers on Academic Achievement among Schoolchildren

Injecting Charter School Best Practices into Traditional Public

Schools: Evidence from Field Experiments

Figlio and Lucas (2004) Do High Grading Standards Affect Student Performance?

Harris and Sass (2014) Skills, Productivity and the Evaluation of Teacher Performance

Fryer (2011) Financial Incentives and Student Achievement:

Evidence from Randomized Trials

Fryer (2014) Injecting Charter School Best Practices into

Traditional Public Schools: Evidence from Field Experiments

Cook et al. (2014) The (Surprising) Efficacy of Academic and

Behavioral Intervention with Disadvantaged Youth: Results from a

Randomized Experiment in Chicago.

Hanushek (1992) The Trade-off between Child Quantity and

Quality

Hastings and Weinstein (2008) Information, School Choice, and

Academic Achievement: Evidence from Two Experiments 
Mecklenburg)

USA: New York

(New York City)

USA: New York

(New York City)

USA: New York

(New York City)

USA: New York

(New York City)

USA: New York

(New York City)

USA: New York

(New York City)

USA: Ohio

(Coshocton)

USA: Texas

(Dallas)

USA: Texas

(Houston)

USA: Washington

USA: Wisconsin

(Milwaukee)

USA: unnamed

USA: unnamed

USA: unnamed

Chile

Chile

Chile

Chile

Chile

Chile
Rockoff et al. (2012) Information and Employee Evaluation: Evidence from a Randomized Intervention in Public Schools Fryer (2011) Financial Incentives and Student Achievement: Evidence from Randomized Trials

Fryer (2013) Teacher Incentives and Student Achievement:

Evidence from New York City Public Schools

Dobbie and Fryer (2013) Getting Beneath the Veil of Effective

Schools: Evidence From New York City

Rockoff et al. (2011) Can You Recognize an Effective Teacher When You Recruit One?

Boyd et al. (2011) The Effectiveness and Retention of Teachers with Prior Career Experience.

Bettinger (2012) Paying to Learn: The Effect of Financial

Incentives on Elementary School Test Scores.

Fryer (2011) Financial Incentives and Student Achievement:

Evidence from Randomized Trials

Fryer (2014) Injecting Charter School Best Practices into

Traditional Public Schools: Evidence from Field Experiments

DeArmond and Goldhaber (2010) Scrambling the Nest Egg: How

Well Do Teachers Understand Their Pensions, and What Do They

Think about Alternative Pension Structures?

Principals' Perceptions of Competition for Students in Milwaukee

Schools.

Barrow, Markman and Rouse (2009) Technology's Edge: The

Educational Benefits of Computer-Aided Instruction.

Jacob and Lefgren (2008) Can Principals Identify Effective

Teachers? Evidence on Subjective Performance Evaluation in

Education.

Jacob and Lefgren (2007) What do Parents Value in Education? An

Empirical Investigation of Parents' Revealed Preferences for

Teachers

Dinkelman and Martinez (2014) Investing in Schooling in Chile:

The Role of Information about Financial Aid for Higher Education

McEvan and Shapiro (2008) The Benefits of Delayed Primary

School Enrollment: Discontinuity Estimates Using Exact Birth

Dates

Paredes (2014) A Teacher Like Me or a Student Like Me? Role

Model Versus Teacher Bias Effect

McEwan (2013) The Impact of Chile's School Feeding Program on Education Outcomes

Anand, Mizala and Repetto (2009) Using School Scholarships to

Estimate the Effect of Private Education on the Academic

Achievement of Low-Income Students in Chile.

McEwan (2003) Peer Effects on Student Achievement: Evidence

from Chile 


\begin{tabular}{|c|c|}
\hline Colombia & $\begin{array}{l}\text { Angrist, Bettinger and Kremer (2006) Long-Term Educational } \\
\text { Consequences of Secondary School Vouchers: Evidence from } \\
\text { Administrative Records in Colombia }\end{array}$ \\
\hline Colombia & $\begin{array}{l}\text { Bettinger, Kremer and Saavedra (2010) Are Educational Vouchers } \\
\text { Only Redistributive? }\end{array}$ \\
\hline Colombia: Bogota & $\begin{array}{l}\text { Barrera-Osorio, Bertrand and Linden (2011) Improving the Design } \\
\text { of Conditional Transfer Programs: Evidence from a Randomized } \\
\text { Education Experiment in Colombia }\end{array}$ \\
\hline Peru & $\begin{array}{l}\text { Beuermann (2014) One Laptop per Child at Home: Short-Term } \\
\text { Impacts from a Randomized Experiment in Peru. }\end{array}$ \\
\hline Uruguay & Manacorda (2012) The Cost of Grade Retention \\
\hline Venezuela & $\begin{array}{l}\text { Ortega (2010) The Effect of Wage Compression and Alternative } \\
\text { Labor Market Opportunities on Teacher Quality in Venezuela. }\end{array}$ \\
\hline China: Beijing & $\begin{array}{l}\text { Lai, Sadoulet and De Janvry (2011) The Contributions of School } \\
\text { Quality and Teacher Qualifications to Student Performance } \\
\text { Evidence from a Natural Experiment in Beijing Middle Schools. }\end{array}$ \\
\hline China: Beijing & $\begin{array}{l}\text { Lai, Sadoulet and De Janvry (2009) The Adverse Effects of Parents' } \\
\text { School Selection Errors on Academic Achievement: Evidence from } \\
\text { the Beijing Open Enrollment Program. }\end{array}$ \\
\hline Benin & $\begin{array}{l}\text { Blimpo (2014) Team Incentives for Education in Developing } \\
\text { Counties: A Randomized Field Experiment in Benin. }\end{array}$ \\
\hline $\begin{array}{l}\text { Kenya: Busia and } \\
\text { Teso }\end{array}$ & Kremer, Miguel and Thornton (2009) Incentives to Learn \\
\hline $\begin{array}{l}\text { Kenya: Busia and } \\
\text { Teso }\end{array}$ & $\begin{array}{l}\text { Glewwe, Kremer and Moulin (2009) Many Children Left Behind? } \\
\text { Textbooks and Test Scores in Kenya }\end{array}$ \\
\hline Kenya & $\begin{array}{l}\text { Lucas and Mbiti (2012) Access, Sorting, and Achievement: The } \\
\text { Short-Run Effects of Free Primary Education in Kenya. }\end{array}$ \\
\hline Uganda & $\begin{array}{l}\text { Reinikka and Svensson (2011) The Power of Information in Public } \\
\text { Services: Evidence from Education in Uganda. }\end{array}$ \\
\hline
\end{tabular}

Note: This table lists studies which make use of administrative data matched with surveys or experiments, and that have been published or announced as forthcoming between January 1990 and July 2014 in the following outlets: American Economic Journal: Applied Economics, American Economic Journal: Economic Policy, American Economic Review, Econometrica, Economic Journal, Economics of Education Review, Education Finance and Policy, Journal of Human Resources, Journal of Labor Economics, Journal of Political Economy, Journal of Public Economics, Quarterly Journal of Economics, Review of Economic Studies, Review of Economics and Statistics and NBER Working Papers: Education Program. All the papers in the table used in the analysis single administrative data set that was matched to survey and/or experimental data. 
Table 4: Survey of papers using administrative education data. Multiple matched administrative sources studies matched to surveys or experiments

(1)

Country/region

\begin{tabular}{|c|c|}
\hline Denmark & $\begin{array}{l}\text { Joensen and Hielsen (2009): Is there a Causal Effect of High School } \\
\text { Math on Labor Market Outcomes? }\end{array}$ \\
\hline Denmark & $\begin{array}{l}\text { Gupta and Simonsen (2010): Non-Cognitive Child Outcomes and } \\
\text { Universal High Quality Child Care. }\end{array}$ \\
\hline Denmark & $\begin{array}{l}\text { Jensen and Rasmussen (2011) The Effect of Immigrant } \\
\text { Concentration in Schools on Native and Immigrant Children's } \\
\text { Reading and Math Skills }\end{array}$ \\
\hline Israel: Tel-Aviv & Lavy (2010) Effects of Free Choice Among Public Schools \\
\hline Norway & Naper (2010) Teacher Hiring Practices and Educational Efficiency \\
\hline Sweden & $\begin{array}{l}\text { Meghir and Palme (2005) Educational Reform, Ability, and Family } \\
\text { Background }\end{array}$ \\
\hline Sweden & $\begin{array}{l}\text { Golsteyn, Gronqvist and Lindahl (2014) Adolescent Time } \\
\text { Preferences Predict Lifetime Outcomes. }\end{array}$ \\
\hline $\begin{array}{l}\text { USA: Illinois } \\
\text { (Chicago) }\end{array}$ & $\begin{array}{l}\text { Arteaga et al. (2014) One Year of Preschool or Two: Is It Important } \\
\text { for Adult Outcomes? }\end{array}$ \\
\hline $\begin{array}{l}\text { USA: Illinois } \\
\text { (Chicago) }\end{array}$ & $\begin{array}{l}\text { Jacob, Kapustin and Ludwig (2014) Human Capital Effects of Anti- } \\
\text { Poverty Programs: Evidence from a Randomized Housing Voucher } \\
\text { Lottery. }\end{array}$ \\
\hline Chile & $\begin{array}{l}\text { Bharadwaj, Loken and Neilson (2013) Early Life Health } \\
\text { Interventions and Academic Achievement }\end{array}$ \\
\hline
\end{tabular}

Note: This table lists studies which make use of administrative data matched across multiple registers and additionally to non-administrative based data source, and that have been published or announced as forthcoming between January 1990 and July 2014 in the following outlets: American Economic Journal: Applied Economics, American Economic Journal: Economic Policy, American Economic Review, Econometrica, Economic Journal, Economics of Education Review, Education Finance and Policy, Journal of Human Resources, Journal of Labor Economics, Journal of Political Economy, Journal of Public Economics, Quarterly Journal of Economics, Review of Economic Studies, Review of Economics and Statistics and NBER Working Papers: Education Program. All the papers in the table used in the analysis at least two administrative data sets that were matched together, and then further matched to survey and/or experimental data. 